\title{
JOB CHARACTERISTICS AND LABOR MARKET DISCRIMINATION IN PROMOTIONS: NEW THEORY AND EMPIRICAL EVIDENCE
}

\author{
by \\ Jed DeVaro* \\ Department of Labor Economics \\ Cornell University \\ 357 Ives Hall East \\ Ithaca, NY 14853 \\ E-mail: devaro@cornell.edu \\ and \\ Suman Ghosh \\ Department of Economics \\ Florida Atlantic University \\ 777 Glades Road \\ Boca Raton, FL 33431 \\ E-mail: sghosh@fau.edu \\ and \\ Cindy Zoghi \\ Bureau of Labor Statistics \\ Washington, D.C. \\ E-mail: Zoghi.Cindy@bls.gov
}

August 4, 2007

\section{PRELIMINARY DRAFT. PLEASE DO NOT CITE WITHOUT PERMISSION.}

Keywords: Discrimination, Promotions, Asymmetric Information JEL Classification: D82, J71

\footnotetext{
* We thank Mike Waldman, Chinhui Juhn and seminar participants at the 2007 Society of Labor Economists Annual Meeting, the $5^{\text {th }}$ International Industrial Organization Conference, Trans-Pacific Labor Seminar, RPI, the Bureau of Labor Statistics, UC-Riverside, and Florida Atlantic University for helpful comments, and Wally Hendricks, Mike Gibbs, and Kevin Hallock for providing access to the data. Henri Fraisse provided excellent research assistance. All views expressed in this paper are those of the authors and do not necessarily reflect the views or policies of the Bureau of Labor Statistics.
} 


\title{
JOB CHARACTERISTICS AND LABOR MARKET DISCRIMINATION IN PROMOTIONS: NEW THEORY AND EMPIRICAL EVIDENCE
}

\begin{abstract}
We present new theory and the first empirical test of promotion discrimination models based on job assignment signaling. In our theory, promotions serve as signals of worker ability, and job hierarchies differ in the degree to which tasks vary across hierarchical levels. When tasks differ substantially across levels, the opportunity cost (in terms of foregone output) of not promoting qualified workers from a disadvantaged group (e.g. racial minorities or females) is large, so employers are less likely to (inefficiently) retain such workers in lower-level jobs. Thus, given performance in the pre-promotion job, the extent to which disadvantaged workers have lower promotion probabilities than advantaged workers should decrease when tasks vary more across hierarchical levels. Also, the difference between the favored and disfavored groups in the wage increase attached to promotion should diminish when tasks vary more across hierarchical levels. We test these implications empirically for the case of racial discrimination in promotions, using personnel data from a large U.S. firm and also data from the National Compensation Survey. We find strong empirical support for the theoretical model's predictions concerning promotion probabilities, whereas empirical support is mixed for the model's predictions concerning the wage growth attached to promotions.
\end{abstract}




\section{INTRODUCTION}

It is well established that racial minorities and women tend to fare worse than whites and men in a number of measurable labor market outcomes. While racial and gender differences in preferences and productivity may explain part of these differences in labor market outcomes, it is frequently argued that discrimination also plays a role. There is now a voluminous literature on labor market discrimination, and it focuses heavily on discrimination in wages and hiring decisions. Discrimination in promotion decisions has been studied less frequently and is the subject of our analysis. By discrimination in promotion decisions we mean a situation in which workers from a disadvantaged group (e.g. racial minorities or women) are promoted less frequently in equilibrium than are observably similar workers from an advantaged group (e.g. whites or men) who have the same job performance in a given position.

A potential theoretical explanation for discrimination in promotion decisions was proposed in Milgrom and Oster (1987), building on Waldman's (1984) model describing the signaling role of promotions. The central feature of their model is an informational asymmetry, whereby a worker's current employer observes the worker's productivity perfectly whereas other employers in the market only observe the worker's job assignment (i.e. whether the worker was promoted), interpreting this assignment as a signal of the worker's ability. Their theory assumes there are two types of workers: Visibles (e.g. white or males) are workers whose abilities are known to all potential employers, whereas Invisibles (e.g. minorities or females) are workers whose abilities can be concealed by the employer from other potential employers. The idea behind this "Invisibility Hypothesis" is that workers with advantaged backgrounds are more likely to be recognized for their abilities by potential employers. One interpretation of this concerns social networking; whites and/or males may benefit from "old boys' club" connections that make their skills more visible to prospective employers. ${ }^{1}$ An

\footnotetext{
${ }^{1}$ To justify their "Invisibility Hypothesis", Milgrom and Oster (1987) provide the following elaboration: "There are many causes contributing to the relative lack of recognition for disadvantaged workers. Prejudice - in the form of misperceptions rather than antipathy - can cause an employer to overlook a potentially good employee. So, too, can the failure of an employee to 'toot his own horn,' whether the reluctance to do so comes from shyness, or pride, or cultural taboos. The existence of clubs that limit the membership of women, nonwhites, or religious or ethnic minorities; job segregation which is not per se inefficient but which keeps some people out of view; exclusive neighborhoods; out-of-town conventions that are hard for some working mothers to attend - all of these things contribute to a separation that makes
} 
implication of the informational asymmetry that is assumed for Invisibles is that employers with private information about their workers' productivities can earn excess profits on highly productive Invisibles, since the talents of these workers are unobserved by competing employers. Hence, discrimination in promotions exists whereby some high-ability Invisibles are inefficiently denied promotions.

The first of two main objectives in our paper is to extend signaling models such as the Milgrom and Oster analysis in a way that allows us to generate testable implications. We construct a theoretical model that incorporates human capital investment decisions on the part of workers, strategic promotion decisions on the part of employers, asymmetric information about worker ability, and a two-level job hierarchy. A central feature of our argument concerns the degree to which tasks vary across levels of the job hierarchy. We show that if job tasks vary substantially across hierarchical levels, then the inefficiency in promotion decisions identified by Milgrom and Oster (whereby some high-ability Invisibles are denied promotions) can be mitigated. On the other hand, if the tasks associated with the different levels are broadly similar then there is more discrimination in promotion decisions for Invisibles.

Our second main objective is to evaluate the testable implications of our model empirically, using personnel data from a large U.S. firm and from the National Compensation Survey (NCS). The personnel data contain information on promotions, wages, job performance, and personal characteristics. The NCS data contain information on job characteristics, allowing us to construct within-occupation measures of the degree to which tasks vary across levels of a job hierarchy. Although our theory could be applied equally well to study discrimination against racial minorities, women, or any other group that is thought to be "invisible" to the outside market, in this paper we focus only on racial discrimination. This is because, in the firm we analyze, significant differences in promotion rates exist between whites and nonwhites but not between men and women. Clearly, in other firms, discrimination against women may be important even though it is apparently not in the firm we study.

some workers less visible to potential new employers." A micro-foundation for this assumption is provided in Mishra (2003). 
Our empirical results strongly support our theory's implications concerning the probability of promotion. That is, we find that promotion probabilities are lower for nonwhites than for whites, ceteris paribus, and that this racial difference in promotion probabilities is mitigated in job hierarchies that demonstrate significant variability of tasks across hierarchical levels. We find mixed empirical support for the theory's implications for the wage growth attached to promotions. On the one hand, we find support for the prediction that the wage growth attached to promotion is higher for nonwhites than whites. On the other hand, our empirical results do not support the prediction that the racial difference in wage growth just described is mitigated when tasks become more variable across hierarchical levels. Later in the paper we provide a potential explanation for the mixed support of the predictions regarding wage growth.

To illustrate one of the central ideas in our theory, consider an example that compares two job hierarchies arising in different production contexts. The first consists of assistant professors (at the low level) and tenured associate professors (at the high level). Both jobs in this hierarchy involve virtually the same tasks (namely research, teaching and advising, and administrative responsibilities, though the mix of these tasks frequently changes somewhat following a promotion to associate professor). ${ }^{2}$ The second hierarchy consists of technicians (at the low level) and general managers (at the high level). In this case, tasks change significantly when a worker is promoted from technician to general manager. We show in this paper that discrimination in promotions should be more pronounced in the first hierarchy than in the second.

The logic behind this result is as follows. Invisibles deciding whether to invest in costly human capital accumulation early in their careers face the following problem, arising from a double moral hazard problem in the promotion process. The firm wants these workers to invest in productivity-enhancing human capital. Since such investments increase the likelihood of promotion (and an accompanying wage increase), the prospect of promotion serves as an incentive for workers to invest. On the other hand, after Invisibles have invested the firm might choose not to promote them, so as to avoid

\footnotetext{
${ }^{2}$ We use this example simple to illustrate a hierarchy characterized by similar tasks across levels, abstracting from the up-or-out nature of contracts in academia. However, similarity in tasks across hierarchical levels in academia, law, and the military has also been considered in explaining the prevalence of up-or-out contracts in these settings. Kahn and Huberman (1988), O'Flaherty and Siow (1995) and Ghosh and Waldman (2006) are some papers in that vein.
} 
sending a positive signal to other firms in the market about these workers' abilities. Since wages are determined by spot market contracts, and since a promotion sends a positive signal to all firms in the market about a worker's ability, a promotion necessitates giving the worker a wage increase to prevent him from being stolen by a rival firm. Thus, to avoid paying this wage increase the employer might inefficiently choose not to promote the worker. Since Invisibles foresee this and will therefore be reluctant to invest in human capital, the firm faces a commitment problem in convincing such workers to invest. The commitment problem disappears, however, if the productivity of a promoted Invisible is sufficiently high in the high-level job relative to productivity in the low-level job. In that case, it is beneficial for the firm to promote the Invisible who has invested in human capital, even at the cost of sending a positive signal to the market of this worker's ability. Thus, Invisibles are willing to invest in human capital and can be assured that such investments will enhance their promotion prospects. This scenario in which the commitment problem disappears arises when the job tasks differ substantially across hierarchical levels, so that the worker's productivity differs significantly between the two jobs and the opportunity cost (in terms of the worker's foregone output in the high-level job) of not promoting the Invisible is large. Note that in the case of Visibles, the firm never has an incentive to inefficiently withhold promotions from these workers, since their abilities are publicly observed by all firms in the market. The result is that the ability threshold beyond which a worker gets promoted is higher for Invisibles than for Visibles. ${ }^{3}$

To summarize, discrimination against Invisibles in promotion decisions is mitigated if the gain to the employer in correctly assigning the worker to the high-level job through a promotion is high enough to compensate for the loss (in terms of higher wage costs) of signaling the worker to be of high ability. This is the case when the tasks in both job levels differ substantially. In contrast, if the tasks at both job levels are broadly similar (as is the case, for example, in law firms, academic institutions, medical institutions and the military) more discrimination against Invisibles should be observed. ${ }^{4}$

\footnotetext{
${ }^{3}$ Some empirical evidence of higher promotion standards for women than men can be found in Pekkarinen and Vartianen (2003), Winter-Ebmer and Zweimuller (1997), and Jones and Makepeace (1996).

${ }^{4}$ While not conclusive evidence of discrimination, there is evidence that females are under-represented in these fields. Spurr (1990) shows that although the proportion of female lawyers has grown rapidly in
} 
From a welfare perspective, the problem of inefficient promotions is exacerbated by inefficient human capital acquisition on the part of Invisibles. An implication of the analysis in Milgrom and Oster (1987) is that discrimination in promotion decisions can persist even absent any shared tastes for discrimination by any market actors. The empirical prediction of our model is that, controlling for other factors and in particular for worker performance in the low-level job, in hierarchies where job tasks are broadly similar across levels the degree of discrimination in promotions against Invisibles should be greater than in hierarchies where the tasks differ substantially across levels. ${ }^{5}$

In addition to contributing to the literature on discrimination in promotions, our analysis contributes to a growing literature on the role of asymmetric learning in labor markets (e.g. Greenwald (1986), Lazear (1986), MacLeod and Malcomson (1988), Gibbons and Katz (1991), Doiron (1995), Grund (1999), Pinkston (2004), and Schonberg (2004)). The application of asymmetric learning to the context of promotion decisions, in particular the idea that promotions serve as a signal of worker ability, was first developed in Waldman (1984), and this idea has received considerable attention in the subsequent theoretical literature (e.g. Milgrom and Oster (1987), Ricart i Costa (1988), Waldman (1990), Bernhardt (1995), Chang and Wang (1996), Zabojnik and Bernhardt (2001), Owan (2004), and Golan (2005)). Despite the importance of the promotion-as-signal hypothesis in the theoretical literature, until recently the idea had not been tested

\footnotetext{
recent years there is evidence that women are promoted less frequently to partnership in major U.S. law firms. Similarly, Rhode (2001) finds that "women in the legal profession remain underrepresented in positions of greatest status, influence, and economic reward. They account for only $15 \%$ of federal judges and law firm partners, $10 \%$ of law school deans and 5\% of managing partners of large firms". She finds that under-representation of women of color is still greater. Similar evidence from the legal profession is found in Padavic and Reskin (2003) and Gorman (2001). In two studies of academia, Ginther and Hayes $(1999,2003)$ find that substantial gender differences in promotion to tenure exist after controlling for productivity, demographic characteristics, and primary work activity in the humanities. DeAngelis (2000) finds that only 10 percent of females graduating from medical school between 1979 and 1993 advanced to the level of medical school faculty. Evidence from the military shows that women's representation in the officer ranks was about equal to their representation in the enlisted ranks (Manning and Wight 2000), but female and minority officers were concentrated in less-prestigious administrative and supply areas and underrepresented in tactical operations, from which two-thirds of the general and flag officers were drawn. ${ }^{5}$ Note that this result would not obtain in the Milgrom-Oster framework. There, the most productive Invisibles are not promoted because there is no way for the firm to make any rent off of them once they are promoted. In our model the firm can earn rents because of firm-specific human capital combined with the hierarchical structure.
} 
empirically. Another contribution of our analysis, therefore, is to add to a newly emerging empirical literature on the signaling role of promotions. ${ }^{6}$

\section{BACKGROUND AND PREVIOUS LITERATURE}

To set the stage for our theoretical and empirical analysis, in this section we survey the theoretical literature on discrimination and some alternative theoretical explanations for racial and gender differences in promotions, as well as summarizing the empirical literature on racial and gender differences in promotions. Although our empirical work focuses only on racial differences, in this section we also discuss the literature on gender differences since our theory provides a basis for analyzing gender discrimination in future research using other data.

The theoretical literature offers a number of potential explanations for discrimination in the workplace. The two main theories of discrimination are those based on tastes (or personal prejudice) following Becker (1957) and those based on statistical discrimination following Phelps (1972) and Arrow (1973). Taste-based theories assume that members of one group in the workplace have distaste for interacting with members of another group (e.g. white supervisors may have distaste for hiring nonwhite employees, white workers may have distaste for working with nonwhite co-workers, or white customers may have distaste for consuming goods and services produced by nonwhite workers). Theories of statistical discrimination, on the other hand, assume that employers have imperfect information about potential workers' skills and productivity, treating race or gender as signals of these characteristics. Thus, individuals from different groups may be treated differently by the employer in equilibrium even if they

\footnotetext{
${ }^{6}$ DeVaro and Waldman (2006) is the first study to test empirically the promotion-as-signal hypothesis, finding support for the theory using personnel data from a single, large American firm in the financial services industry. In that analysis, workers were differentiated by their (publicly observable) education levels, with higher educational attainment being associated with higher ability levels on average. Consistent with the promotion-as-signal hypothesis, evidence of inefficient promotion decisions was found to be strongest for the least-educated workers. The logic is that the positive signal that the market receives when such workers are promoted is larger than the corresponding signal for higher-educated workers, since the latter are already perceived as high ability by the market. A corroborating result was found in Belzil and Bognanno (2005). Using an eight-year panel of promotion histories of 30,000 American executives, they found that the promotion probability is decreasing in the level of educational attainment. In the present analysis, the relevant distinction between workers is not educational attainment but rather race and gender, with the prediction that inefficiency in promotions should exist to a greater extent for the disadvantaged Invisibles (i.e. racial minorities or women) as previously explained.
} 
are equally productive and otherwise observably similar. More recently, Lundberg and Startz (1983) and Coate and Loury (1993) have extended the statistical theory of discrimination to include human capital decisions by the workers. Coate and Loury show that, even when identifiable groups are equally endowed ex ante, affirmative action can create a situation in which employers (correctly) perceive the groups to be unequally productive, ex post.

Athey, Avery and Zemsky (2000) argue that the taste-based and statistical theories are best suited for explaining discrimination in hiring rather than in promotion decisions. They offer an alternative theory of discrimination in promotions to the signaling perspective offered in Milgrom and Oster (1987) and in our analysis. In particular, they study how diversity evolves at a firm with entry-level and upper-level employees who vary in ability and type. Their logic is based on mentoring and the dynamic consequences of having fewer mentoring opportunities for the lower-level employees.

A theoretical explanation for gender discrimination in promotion decisions is developed in Lazear and Rosen (1990). They present a model in which promotion rates are lower for females than for equally productive males. This arises because, while equally productive in market work, women have a comparative (and absolute) advantage in the nonmarket sector. Women are therefore more likely than men to separate from the firm. Since the social cost of a departure is greater for the worker in the high-level job than in the low-level job, given ability, males are promoted to the high-level job over females who are equally productive in the low-level job.

The empirical literature on gender differences in promotions has yielded mixed results, though evidence of promotion differences favoring females is less common than the reverse case. A recent analysis of promotions using data from a cross section of establishments found lower rates of promotion for women than for men with similar observed characteristics and the same job-specific performance ratings (Blau and DeVaro 2007). Other studies have found similar results using different data (Cabral, Ferber, and Green, 1981; Olson and Becker, 1983; Cannings 1988; Spurr 1990; McCue 1996; Jones and Makepeace, 1996; Cobb-Clark 2001; Gjerde 2002; Ransom and Oaxaca 2005; Acosta 2006). In contrast, studies such as Stewart and Gudykunst (1982), Gerhart and 
Milkovich (1989), and Hersch and Viscusi (1996) have found the reverse result. Lewis (1986) found no gender difference in promotion rates among comparable federal whitecollar workers; Powell and Butterfield (1994) found no evidence of a "glass ceiling" for women in a study of promotion decisions to federal government Senior Executive Service positions; and Giuliano, Levine, and Leonard (2005) found no gender difference in promotion rates, using data from a single, large, U.S. retail employer. In a longitudinal study of individual educators in Oregon and New York, Eberts and Stone (1985) found that a gender difference favoring males in the early 1970s diminished and became insignificant by the late 1970s, arguing that equal opportunity employment enforcement contributed to the decline. ${ }^{7}$

The empirical literature on racial differences in promotion rates has been more consistent in its conclusions than the literature on gender differences. The most frequent finding is that nonwhite workers have lower promotion rates than white workers. In other cases no difference in promotion rates is found, though it is virtually never the case that whites have lower promotion rates than nonwhites. Table 1 summarizes the results of some papers in this branch of the literature. In summary, the evidence from the empirical literature on race clearly indicates lower promotion rates for nonwhites than whites, whereas the empirical literature on gender is more mixed (though promotion rates favoring men appear more common than promotion rates favoring women). Consistent with this literature, in the firm we study there is clear evidence of lower promotion probabilities for nonwhites than whites but no evidence of a gender gap in promotions.

\footnotetext{
${ }^{7}$ While these studies used data from the United States, others have investigated gender differences in promotion rates outside the United States. As a whole, the international evidence is somewhat less favorable to women than is the evidence based on US data. Studies finding lower promotion rates for women include Bamberger, Admati-Dvir, and Harel's (1995) study of two Israeli high-tech companies; Pekkarinen and Vartianinen's (2004) analysis of panel data on Finnish metalworkers; Sabatier and Carrere's (2005) analysis of academic researchers in France; and Ranson and Reeves' (1995) study of computer professionals in a western Canadian city. Wright, Baxter, and Birkelund (1995) compare the U.S., Canada, the U.K., Australia, Sweden, Norway, and Japan, concluding that evidence of lower promotion rates for women is weaker in the U.S. than for the other countries. Using a panel of British households, Booth, Francesconi, and Frank (2003) found that, after controlling for observed and unobserved worker heterogeneity, women are promoted at roughly the same rate as men but receive smaller wage increases from promotion. Also relevant is Winter-Ebmer and Zweimuller's (1997) finding, based on white-collar workers from the Austrian Microcensus, that females have to meet higher ability standards than males to achieve promotions.
} 


\section{THEORETICAL MODEL AND ANALYSIS}

We present the theoretical model and analysis in three parts. In the first, we present the basic setup for the theoretical model. In the second, we present the model's main results and describe the equilibrium, first for Visible workers and then for Invisible workers. In the third, we translate the model's main results into testable implications.

\section{A) Basic Setup}

The starting point for our analysis is the notion that nonwhites (or females) are potentially "invisible" from the perspective of other employers in the market. We consider an economy in which a single good is produced, with its price per unit normalized to one. Firms face perfect competition in the product market, and both workers and firms are risk-neutral with discount rates of zero. Careers last for two periods, and in each period labor supply is perfectly inelastic and fixed at one unit for each worker. We describe workers as "young" in the first period and "old" in the second. Job hierarchies consist of two levels: Job 1 is a lower-level job to which workers are assigned when they enter a particular firm in the first period, and Job 2 is a higher-level job into which some workers are promoted in the second period. Workers have the option to invest in acquiring $\alpha$ units of human capital in the first period, at a cost of $z$. Such an investment has both a general and a specific component. We denote the general component as $\beta$ and the specific component as $\alpha-\beta$, where we require that $1<\beta<\alpha{ }^{8}$

Let $\eta_{\mathrm{i}}$ denote worker i's intrinsic ability. A worker does not observe his ability but knows it is drawn from the uniform distribution on the interval $\left[\eta_{\mathrm{L}}, \eta_{\mathrm{H}}\right]$. Letting $\mathrm{y}_{\mathrm{ijt}}$ denote the output of worker $\mathrm{i}$ in Job $\mathrm{j}$ in Period $\mathrm{t}$, output in both jobs is given by $\mathrm{y}_{\mathrm{ijt}}=$ $k_{i j t}\left(d_{j}+c_{j} \eta_{i}\right)$, where $k_{i j t}$ is a factor that augments output in the second period if the worker has invested in acquiring human capital in the first period. We assume that $\mathrm{k}_{\mathrm{i} 11}=1, \mathrm{k}_{\mathrm{ij} 2}=$ $\alpha$ if the worker invests in human capital in the first period, and $\mathrm{k}_{\mathrm{ij} 2}=1$ if the worker does not invest. We further assume $c_{2}>c_{1}$ and $d_{1}>d_{2}$, so that output grows faster as a function of intrinsic ability in Job 2 than in Job 1. This implies a smooth rising job ladder for workers, in which it is efficient for the employer to promote higher-ability workers. To make the case of promotion interesting, we assume $d_{1}+c_{1} \eta_{H}<d_{2}+c_{2} \eta_{H}$, so that a

\footnotetext{
${ }^{8}$ Later we impose a more specific restriction on $\alpha$.
} 
positive fraction of the workers are more productive in Job 2 than in Job 1. Otherwise, old workers would always be retained in Job 1 . We write this condition in terms of $c_{2}$ as follows:

$$
\mathrm{c}_{2}>\mathrm{c}_{1}+\Delta, \text { where } \Delta=\left(\mathrm{d}_{1}-\mathrm{d}_{2}\right) / \eta_{\mathrm{H}}
$$

We define $\eta^{\prime}$ as the level of ability for which a worker is equally productive in Jobs 1 and 2. That is, $\eta^{\prime}$ is defined by the following equation: $d_{1}+c_{1} \eta^{\prime}=d_{2}+c_{2} \eta^{\prime}$, so that $\eta^{\prime}=\left(d_{1}-\right.$ $\left.\mathrm{d}_{2}\right) /\left(\mathrm{c}_{2}-\mathrm{c}_{1}\right)$.

An important point concerns our interpretation of changes in $c_{2}$. Holding $c_{1}$ constant, an increase in $c_{2}$ implies an increase of worker productivity in Job 2 relative to Job 1. A natural interpretation concerns the degree to which tasks vary across levels of the job hierarchy. For example, when both Jobs 1 and 2 involve tasks that are very similar (the case of a relatively small difference between $c_{2}$ and $c_{1}$ ), there will not be much difference between a worker's productivity in Job 1 and his productivity in Job 2. In this case, the cost to the firm (in terms of the worker's foregone output in Job 2) of not promoting a worker out of Job 1 is relatively modest, since the worker is doing basically the same work in either job, meaning his productivity is roughly the same in either job. In contrast, when the tasks in Job 2 differ greatly from those in Job 1 (the case in which $c_{2}$ is high relative to $c_{1}$, meaning the worker's productivity in Job 2 is high relative to productivity in Job 1), the firm incurs greater costs of foregone output in Job 2 by retaining high-ability workers in Job 1 rather than promoting them. ${ }^{9}$

We distinguish between two types of workers: Visibles and Invisibles. At the end of the first period, the first-period productivity of Visibles is perfectly observed and verifiable both by their initial employers and by all outside firms. In contrast, the productivity of Invisibles is private information for the initial employer, while outside firms observe only the worker's job assignment (i.e. whether a promotion occurs). The first-period wage is determined by the zero-profit condition of the firm for the worker's entire career.

\footnotetext{
${ }^{9}$ Here we implicitly assume that in tasks that are more complex it is better to promote higher ability workers, which in fact translates into a higher marginal product. There are two effects. First, higher-ability jobs value ability more highly, so that those with high performance in the lower level jobs are the ones promoted. Second, there are differences across jobs in comparative advantage so that those better at Job 1 are those typically with a comparative advantage at Job 1 and are thus not promoted. The more recent literature, such as Gibbons and Waldman (1999), implicitly assumes that for most jobs it is the first effect that is most important.
} 


\section{B) Equilibrium Describing Job Assignments for Visibles and Invisibles}

The game begins with Nature assigning each worker a level of ability, $\eta_{i}$. At the beginning of Period 1, firms post wage offers. Young workers allocate themselves amongst firms and are employed in Job 1. A spot market contract specifies the wage that either of these worker types receives while young. ${ }^{10}$ In Period 1, the workers decide whether or not to accumulate human capital. Contingent on the worker's decision to acquire human capital, the worker's second-period wage and firm are determined as follows. For Invisibles, after observing the worker's productivity at the end of Period 1, the initial employer decides whether to promote the worker to Job 2. After observing the worker's second-period job assignment, the outside firms bid for the worker, thereby determining the worker's wage in Period 2. The initial employer and all outside firms make simultaneous wage offers, and after observing these the worker accepts a job at the firm that offers the highest wage. ${ }^{11}$ Hence, when entering the labor market a young worker maximizes expected lifetime income minus the cost of investing in human capital, if he chooses to invest.

\section{(a) Visible Workers:}

Our solution concept is Subgame Perfect Nash Equilibrium, and the following proposition describes the equilibrium. All proofs are in Appendix A.

Proposition 1: In the first period, for $\beta$ sufficiently high, all Visibles invest in acquiring human capital. All are assigned to Job 1 in the first period and are paid a wage

$$
\left.W^{l}=d_{1}+c_{1}\left(\left(\eta_{L}+\eta_{H}\right) / 2\right)+X^{l}(\alpha-\beta)\left[d_{2}+c_{2}\left(\left(\eta_{H}+\eta_{L}\right) / 2\right)\right]+\left(1-X^{l}\right)(\alpha-\beta)\left[d_{1}+c_{l}\left(\eta_{H}+\eta_{L}\right) / 2\right)\right],
$$

where $X^{l}$ is the probability that the worker is promoted to Job 2 in the second period and $\left(1-X^{1}\right)$ is the probability that the worker is not promoted. In the second period, Visibles

\footnotetext{
${ }^{10}$ In the case of Invisibles there is no benefit to long-term contracts, so we assume that wages are determined by spot-market contracting. Note further that, since an Invisible's output is privately observed by the worker's employer, any wage specified in such a spot-contract consists of a wage determined prior to production rather than a wage determined by a piece-rate contract where compensation depends on the realization of output.

${ }^{11}$ While the assumption of simultaneous wage offers might appear restrictive (compared with model of Milgrom and Oster (1987) in which the initial employer could make a counter offer), we could generate the same results we derive here by assuming that there is always an exogenous probability of a worker changing jobs irrespective of the wage offer (as in Greenwald 1986).
} 
with ability $\eta_{i} \geq \eta^{\prime}$ are promoted to Job 2 , and those with $\eta_{i}<\eta^{\prime}$ are retained in Job 1 . Promoted workers are paid a wage of $\beta\left(d_{2}+c_{2} \eta_{i}\right)$, and those remaining in Job 1 are paid a wage of $\beta\left(d_{1}+c_{1} \eta_{i}\right)$.

The second-period allocation of workers to jobs is efficient for Visibles because there is perfect information about their ability. Furthermore, as long as the general component of human capital is sufficiently high, workers choose to invest in human capital so as to achieve higher second-period wages. ${ }^{12}$ The point is that the workers' second-period wages correspond to the output the workers would have generated if employed at any of the firms in the outside market, and outside employers value the general component of a worker's human capital. In contrast, if human capital investments were entirely firm-specific then none of the workers would have invested, since firms in the outside market would not value these skills and would not be willing to pay for them. In that case, there is no incentive for the initial employer to compensate workers for investments in specific human capital.

\section{(b) Invisible Workers:}

For Invisibles, we analyze the problem as an extensive-form game with imperfect information (Harsanyi 1967, 1968, 1969). Our solution concept is "market-Nash" equilibrium where, given the initial employer's strategy, the market has a strategy which is consistent with what would result from competition among a large number of firms. Similarly, given the market's strategy, the initial employer maximizes expected profits. The consequence is that the market strategy must everywhere be consistent with a zeroexpected-profit constraint. ${ }^{13}$ To overcome the problem of multiple equilibria, we place the following two restrictions on the strategies of the players. First, given that the market is employing its specified strategy, a first-period employer cannot be indifferent between his own specified strategy and some other strategy: the strategy of the first-period

\footnotetext{
${ }^{12}$ See the proof of Proposition 1 for an exact threshold for $\beta$.

${ }^{13}$ Suppose that the first-period employer's strategy is such that a worker is assigned to Job 1 at wage rate $\mathrm{W}$ if and only if the worker's ability is between $\eta^{1}$ and $\eta^{2}$. Then the market-Nash equilibrium implies that the market's wage offer must equal $\max \left\{d_{2}+c_{2}\left(\left(\eta^{1}+\eta^{2}\right) / 2\right), d_{1}+c_{1}\left(\left(\eta^{1}+\eta^{2}\right) / 2\right)\right\}$. When we refer to expected output, we mean "given the job assignment that maximizes the expectation."
} 
employer must be a unique optimal strategy. Second, given that the job assignment is fixed, the market wage offer must be a continuous function of the first-period employer's wage offer. ${ }^{14}$ These two restrictions eliminate implausible equilibria. We shall refer to an equilibrium that satisfies these additional restrictions as a "restricted market-Nash" equilibrium. ${ }^{15}$ Finally, we impose a restriction on the cost of human capital investment, $\mathrm{z}$, assuming that it is not so high as to prevent workers from ever investing, nor is it so low that there is always investment (in which case the issue of the type of contracts to provide incentives for workers to invest in human capital is irrelevant). Later we will impose a more precise range for $\mathrm{z}$. In what follows, we solve the game backwards, considering first the promotion decision of the employer at the beginning of Period 2 and then deriving the investment decision of the worker at the beginning of Period 1.

\section{(i) Employer Behavior}

We now derive the minimum ability threshold, $\eta^{*}$, such that workers above that ability level are promoted by the firm. If worker $\mathrm{i}$, who has acquired human capital in the first period, is promoted to Job 2 in the second period, the worker's productivity is $\mathrm{y}_{\mathrm{i} 22}=$ $\alpha\left(d_{2}+c_{2} \eta_{i}\right)$. If the same worker is retained in Job 1 , his productivity is $y_{i 12}=\alpha\left(d_{1}+c_{1} \eta_{i}\right)$. The worker's wages are determined by the wage offers of the firms in the outside market. In the eyes of the outside market, a worker promoted to Job 2 has an average ability of $\left(\eta^{*}+\eta_{\mathrm{H}}\right) / 2$, and a worker retained in Job 1 has an average ability of $\left(\eta^{*}+\eta_{\mathrm{L}}\right) / 2$. Hence, the corresponding wages that the worker is paid in Jobs 2 and 1 are $\beta\left\{d_{2}+c_{2}\left(\eta^{*}+\eta_{H}\right) / 2\right\}$ and $\left.\beta\left\{d_{1}+c_{1}\left(\eta^{*}+\eta_{L}\right) / 2\right)\right\}$, respectively. ${ }^{16}$ We impose the condition $\alpha>\eta_{H} / \eta_{L}$, which is sufficient to ensure that workers will not be fired from the initial firm. This condition implies that the accumulated human capital is high enough so that it is beneficial for the firm to keep the lowest ability worker in either Job 1 or Job 2 if he has invested.

\footnotetext{
${ }^{14}$ This is similar to a restriction suggested in Milgrom and Roberts (1982).

${ }^{15}$ This equilibrium concept was used by Waldman (1984).

${ }^{16}$ More precisely, the outside offer to promoted workers is given by $\max \left\{\beta\left(\mathrm{d}_{2}+\mathrm{c}_{2}\left(\eta^{*}+\eta_{\mathrm{H}}\right) / 2\right)\right.$, $\left.\beta\left(\mathrm{d}_{1}+\mathrm{c}_{1}\left(\eta^{*}+\eta_{\mathrm{H}}\right) / 2\right)\right\}$.
} 
To derive $\eta^{*}$, we equate the employer's profit when the worker is retained in Job 1 to the profit when the worker is promoted to Job 2, given that the worker invests in human capital. Thus, the following equation defines $\eta^{*}$ :

$$
\alpha\left(d_{2}+c_{2} \eta^{*}\right)-\beta\left[d_{2}+c_{2}\left(\eta^{*}+\eta_{H}\right) / 2\right]=\alpha\left(d_{1}+c_{1} \eta^{*}\right)-\beta\left[d_{1}+c_{1}\left(\eta^{*}+\eta_{L}\right) / 2\right]
$$

Therefore:

$$
\begin{aligned}
\eta^{*} & =\frac{2(\alpha-\beta)\left(d_{1}-d_{2}\right)+\beta\left(c_{2} \eta_{H}-c_{1} \eta_{L}\right)}{\left(c_{2}-c_{1}\right)(2 \alpha-\beta)} & & \text { for } \eta_{L} \leq \eta^{*} \leq \eta_{H} \\
& =0 & & \text { otherwise }
\end{aligned}
$$

Thus, a given value of $\alpha$ implies a corresponding value of $\eta^{*}$ that represents the ability of the marginal worker promoted by the firm.

Recall that in the full information case corresponding to Visible workers, the minimum ability threshold determining promotions is $\eta^{\prime}$, as given by the following expression: $\eta^{\prime}=\left(d_{1}-d_{2}\right) /\left(c_{2}-c_{1}\right)$. Comparing this expression to (2), and using the condition $\mathrm{d}_{1}-\mathrm{d}_{2}<\left(\mathrm{c}_{2}-\mathrm{c}_{1}\right) \eta_{\mathrm{H}}$, we establish the following lemma:

\section{Lemma 1: $\eta^{\prime}<\eta^{*}$}

This result reveals the inefficiency in promotions that arises from asymmetric information. In the case of Visibles, for which the employer and the outside firms observe the output of the worker perfectly at the end of the first period, the proportion of workers promoted was $\left(\eta_{H}-\eta^{\prime}\right) /\left(\eta_{H}-\eta_{L}\right)$, while for Invisibles it is only $\left(\eta_{H}-\eta^{*}\right) /\left(\eta_{H}-\right.$ $\left.\eta_{L}\right)$. Some workers who would be promoted in the case of symmetric information are instead retained in Job 1 so that the initial employer may conceal the true ability of these workers from the outside market. ${ }^{17}$ Next we perform comparative statics on the ability threshold for promotion of Visibles and Invisibles. Lemma 2 shows how changes in $c_{2}$ affect the promotion thresholds of Visibles and Invisibles.

\footnotetext{
${ }^{17}$ Note that if $\alpha$ were to equal 1 in equation (2), then $\eta^{*}>\eta_{\mathrm{H}}$. Intuitively, when human capital investment does not augment output then no promotions occur. Thus, our restriction that $\alpha$ is strictly positive ensures that the promotion case is interesting.
} 
Lemma 2: $d\left(\eta^{*}-\eta^{\prime}\right) / d c_{2}<0$

Recalling that $c_{2}$ is the slope of the output function for Job 2 and that an increase in $c_{2}$, holding $c_{1}$ fixed, raises the productivity of a worker in Job 2 relative to Job 1, we now study the effect of an increase in $c_{2}$, holding $c_{1}$ and $d_{1}$ fixed. Note that $d_{2}$ need not remain fixed and might decrease as $c_{2}$ increases. We make no assumption regarding whether decreases in $\mathrm{d}_{2}$ accompany increases in $c_{2}$, and our effect of primary interest (stated in Lemma 2) is insensitive to such assumptions. However, the magnitude of the decrease in $d_{2}$ that may accompany an increase in $c_{2}$ determines whether $\eta^{\prime}$ decreases, stays the same, or increases. ${ }^{18}$ Another important point concerns the sign of $\mathrm{d \eta}^{*} / \mathrm{dc}_{2}$. From the proof of Lemma 2 we know that: $\frac{\partial \eta^{*}}{\partial c_{2}}=\frac{1}{\left(c_{2}-c_{1}\right)}\left[Y \eta^{\prime}-\eta^{*}\right]+Y \cdot \frac{\partial \eta^{\prime}}{\partial c_{2}}$. Since 0 $<\mathrm{Y}<1$, and since $\eta^{\prime}<\eta^{*}$, the first term on the right-hand side is negative, while the sign of the second term is determined by the sign of $\mathrm{d}^{*}{ }^{*} / \mathrm{dc}_{2}$, which in turn depends on whether (and by how much) $d_{2}$ decreases as $c_{2}$ increases.

Next we analyze worker behavior for the case of Invisibles. To guarantee existence, we impose the following restriction on $\mathrm{z}: \phi\left(\mathrm{c}_{1}+\Delta\right)<\mathrm{z}<\phi\left(\mathrm{c}_{2}{ }^{\prime \prime}\right)$, where $\phi\left(\mathrm{c}_{2}\right)=$ $\beta\left[d_{2}+c_{2}\left(\eta^{*}+\eta_{H}\right) / 2-\left\{d_{1}+c_{1}\left(\eta^{*}+\eta_{L}\right) / 2\right\}\right]\left[\left(\eta_{H}-\eta^{*}\right) /\left(\eta_{H}-\eta_{L}\right)\right]$. In this expression, $c_{2}{ }^{\prime \prime}$ is the upper bound on $c_{2}$, and $\left(c_{1}+\Delta\right)$ is the lower bound on $c_{2}$, above which the issue of promotion makes sense, which comes from equation (1). ${ }^{19}$

\footnotetext{
${ }^{18}$ Looking ahead to the empirical work, this means that any assumption made about how $\mathrm{d}_{2}$ decreases as $\mathrm{c}_{2}$ increases would affect only the predicted sign of the "main effect" of task variability on promotion probability. This sign on the estimate of the main effect is usually negative in our data, so that the probability of promotion decreases when tasks become more variable across hierarchical levels. This result is consistent with a decrease in $\mathrm{d}_{2}$ in the theoretical model that is large enough in magnitude so that $\mathrm{d}^{\prime} / \mathrm{dc}_{2}$ $>0$, though we also find evidence in the data (for very high values of task variability) that $\mathrm{d} \eta^{*} / \mathrm{dc}_{2}<0$ is possible. Given that $\eta^{\prime}<\eta^{*}$ (from Lemma 1), Lemma 2 implies that the disparity in promotion probabilities between Visibles and Invisibles decreases as task variability increases. There are two effects present when $\mathrm{d} \eta^{\prime} / \mathrm{dc}_{2}>0$. The first is that as variability increases it is more difficult to get promoted, and the second is the "inefficient promotion effect" $\left(\eta^{*}>\eta^{\prime}\right)$. As task variability increases, the first effect is the same for both Visibles and Invisibles, but the second (which is not present for Visibles) improves the promotion prospects for the Invisibles relative to the Visibles when task variability increases.

${ }^{19}$ Note that for $c_{2}>c_{2}{ }^{*}$ there are multiple equilibria, one of which involves no workers investing in human capital. We assume that the workers can coordinate behavior such that the realized equilibrium is the one that is Pareto optimal for the workers in that period. Another way to state this is that we restrict attention to Perfectly Coalition-Proof Nash equilibria (Bernheim, Peleg, and Whinston 1987). The assumption is reasonable and permits a neat characterization.
} 


\section{(ii) Worker Behavior}

A promoted Invisible is paid a wage of $\beta\left[\mathrm{d}_{2}+\mathrm{c}_{2}\left(\eta^{*}+\eta_{\mathrm{H}}\right) / 2\right]$, while if he is retained in Job 1 his wage is $\beta\left[d_{1}+c_{1}\left(\eta^{*}+\eta_{L}\right) / 2\right]$. If the worker invests, then his probability of promotion is $X^{1}=\operatorname{Pr}\left(\eta \geq \eta^{*}\right)=\left(\eta_{H}-\eta^{*}\right) /\left(\eta_{H}-\eta_{L}\right)$, and his probability of not getting promoted is $\operatorname{Pr}\left(\eta<\eta^{*}\right)=\left(\eta^{*}-\eta_{L}\right) /\left(\eta_{H}-\eta_{L}\right){ }^{20}$ This follows from the fact that ability is drawn from a uniform distribution with support $\left[\eta_{L}, \eta_{H}\right]$. Thus, when deciding whether to acquire human capital, a worker weighs the cost of the human capital investment against the expected gain in wages. Hence, a worker invests in human capital if the following inequality holds:

$\beta\left[\mathrm{d}_{2}+\mathrm{c}_{2}\left(\eta^{*}+\eta_{\mathrm{H}}\right) / 2-\left\{\mathrm{d}_{1}+\mathrm{c}_{1}\left(\eta^{*}+\eta_{\mathrm{L}}\right) / 2\right\}\right]\left[\left(\eta_{\mathrm{H}}-\eta^{*}\right) /\left(\eta_{\mathrm{H}}-\eta_{\mathrm{L}}\right)\right] \geq \mathrm{z}$.

The left-hand side of this inequality is the expected gain to the worker from investing in human capital. There exists $\mathrm{a} \mathrm{c}_{2}{ }^{*}$ for which this expression holds with equality, as established in the following proposition: ${ }^{21}$

Proposition 2: For Invisibles, there exists $c_{2}{ }^{*}$ such that in equilibrium, for $c_{2} \geq c_{2}{ }^{*}$, workers invest in human capital, and in the second period workers of ability $\eta \geq \eta^{*}$ are promoted to Job 2 whereas those with ability $\eta<\eta^{*}$ are retained in Job 1. For $c_{2}<c_{2}{ }^{*}$, none of the workers invests and none is promoted in the second period.

The left-hand side of (3) is the product of two terms. The first term, namely the first expression in square brackets and its coefficient $\beta$, is the wage effect, or the increase in wages that workers receive when promoted. The second term, namely the second expression in square brackets, is the ex ante probability of promotion given that the worker invests. From previous analysis we know that the sign of $d \eta{ }^{*} / \mathrm{dc}_{2}$ is determined by the magnitude of the decrease in $d_{2}$ that may accompany an increase in $c_{2}$. The case that is most empirically relevant in our data is that $\mathrm{d}_{2}$ decreases by enough so that $\mathrm{d} \eta{ }^{*} / \mathrm{dc}_{2}$ $>0$, meaning that $\eta^{*}$ increases towards an increasing $\eta^{\prime}$ such that the distance between the

\footnotetext{
${ }^{20}$ A worker of extremely high ability could, in principle, be promoted even without investing in human capital. However, this occurs with probability zero given our assumption $\alpha>\eta_{\mathrm{H}} / \eta_{\mathrm{L}}$, which ensures that workers who invest are at a significant enough advantage than even the highest-ability worker who does not invest.

${ }^{21}$ Note that $\eta^{*}$ is a function of $c_{2}$ although we do not write this explicitly.
} 
two thresholds narrows. This has two effects on the left-hand side of (3). One is the wage effect, which is given by the first term on the left-hand side of (3), and second is the promotion probability effect that is given by the second term on the left-hand side of (3). Note that the wage offered by the outside employers is a monotone function of $\eta^{*}$. Thus, with an increase in $c_{2}$, as $\eta^{*}$ increases, the outside employers know that the average ability of promoted workers is higher and thus bid a higher wage. This increases the first expression in brackets. On the other hand, the second term on the left-hand side of (3), namely the ex ante probability of promotion, $\left[\left(\eta_{\mathrm{H}}-\eta^{*}\right) /\left(\eta_{\mathrm{H}}-\eta_{\mathrm{L}}\right)\right]$, decreases. We show that the wage effect dominates the promotion effect for an increase in $c_{2}$. Essentially, for $\mathrm{c}_{2} \geq \mathrm{c}_{2}{ }^{*}$ both the employers' and the workers' incentives can be satisfied.

\section{C) Testable Implications}

Prior to presenting the theoretical model's testable implications, we introduce some notation. Let $\mathrm{yv}_{\mathrm{v}}{ }^{\mathrm{P}}\left(\mathrm{d}_{1}, \mathrm{~d}_{2}, \mathrm{c}_{1}, \mathrm{c}_{2}\right)$ denote the minimum output level required for a young Visible to be promoted to the higher-level job in the second period of his career in a job hierarchy with parameters $d_{1}, d_{2}, c_{1}$, and $c_{2}$. Similarly, $y_{I}^{P}\left(d_{1}, d_{2}, c_{1}, c_{2}\right)$ denotes the analogous threshold for Invisibles. The differential treatment of Visibles and Invisibles in equilibrium gives rise to our first of four testable implications:

Testable Implication 1: Holding constant worker performance in Job 1, $\mathrm{y}_{\mathrm{V}}{ }^{\mathrm{P}}\left(\mathrm{d}_{1}, \mathrm{~d}_{2}, \mathrm{c}_{1}, \mathrm{c}_{2}\right)$ $<\mathrm{y}_{\mathrm{I}}^{\mathrm{P}}\left(\mathrm{d}_{1}, \mathrm{~d}_{2}, \mathrm{c}_{1}, \mathrm{c}_{2}\right)$.

This follows directly from Lemma 1 and is also a testable implication of Milgrom and Oster (1987). By definition, we know that $\mathrm{yv}_{\mathrm{V}}{ }^{\mathrm{P}}\left(\mathrm{d}_{1}, \mathrm{~d}_{2}, \mathrm{c}_{1}, \mathrm{c}_{2}\right)=\alpha\left(\mathrm{d}_{2}+\mathrm{c}_{2} \eta^{\prime}\right)$ and $y_{\mathrm{I}}^{\mathrm{P}}\left(\mathrm{d}_{1}, \mathrm{~d}_{2}, \mathrm{c}_{1}, \mathrm{c}_{2}\right)=\alpha\left(\mathrm{d}_{2}+\mathrm{c}_{2} \eta^{*}\right)$. From this definition and Lemma 1 it follows that if the parameters of the job hierarchy remain the same, a higher $\eta$ required for promotion to the next level translates directly to a higher output level being required for promotion. Thus, Testable Implication 1 simply recasts Lemma 1 in terms of output rather than ability, implying that the minimum performance level required for Visibles to be promoted is lower than the corresponding threshold for Invisibles, other things equal. 
A second implication of our analysis is that the difference in promotion probabilities between Visibles and Invisibles should be smaller when the tasks differ substantially across levels of the job hierarchy. Let $\xi\left(d_{1}, d_{2}, c_{1}, c_{2}\right)$ denote $y_{I}^{P}\left(d_{1}, d_{2}, c_{1}\right.$, $\left.c_{2}\right)-y_{v}{ }^{P}\left(d_{1}, d_{2}, c_{1}, c_{2}\right)$. For simplicity we refer to this difference as $\xi\left(c_{2}\right)$, since we are interested in varying $c_{2}$ while holding $c_{1}$ and $d_{1}$ constant. Our second testable implication is stated as follows:

Testable Implication 2: Holding constant worker performance in Job 1, consider two different job hierarchies with parameters $\overline{c_{2}}$ and $\overline{\overline{c_{2}}}$, such that, $\overline{c_{2}}<\overline{\overline{c_{2}}}$. Then $\xi\left(\overline{\overline{c_{2}}}\right)<$ $\xi\left(\overline{c_{2}}\right)$, i.e., when task variability across the two jobs is greater the difference in promotion rates between Visibles and Invisibles is smaller.

This follows directly from Lemma 2 . As $c_{2}$ increases (holding constant $c_{1}$ and $d_{1}$ ) the productivity of the worker in Job 2 increases relative to productivity in Job 1, and the distance between $\eta^{\prime}$ and $\eta^{*}$ decreases. We interpret an increase in $c_{2}$ relative to $c_{1}$ as an increase in the degree to which tasks differ between Jobs 1 and 2; when tasks are very different across hierarchical levels, the cost to the employer (in terms of foregone worker output in Job 2) is high if the worker is not promoted. In contrast, if job tasks are similar across levels (the case when $c_{2}-c_{1}$ is small) then the worker has roughly the same productivity in either job, so the employer has less to lose by retaining a worker in Job 1 who would otherwise be promoted. Thus, the difference in the minimum output thresholds for promotion between Invisibles and Visibles decreases as $c_{2}$ increases.

Turning to our third testable implication, let $\mathrm{w}_{\mathrm{I}}^{\mathrm{P}}\left(\mathrm{d}_{1}, \mathrm{~d}_{2}, \mathrm{c}_{1}, \mathrm{c}_{2}\right)$ denote the wage received by a promoted Invisible worker in a job hierarchy with parameters $\mathrm{d}_{1}, \mathrm{~d}_{2}, \mathrm{c}_{1}$, and $c_{2}$, let $\mathrm{w}_{\mathrm{I}}^{\mathrm{NP}}\left(\mathrm{d}_{1}, \mathrm{~d}_{2}, \mathrm{c}_{1}, \mathrm{c}_{2}\right)$ denote the analogous wage for Invisibles who are not promoted. Let $\zeta_{\mathrm{I}}\left(\mathrm{d}_{1}, \mathrm{~d}_{2}, \mathrm{c}_{1}, \mathrm{c}_{2}\right)$ denote $\mathrm{w}_{\mathrm{I}}^{\mathrm{P}}\left(\mathrm{d}_{1}, \mathrm{~d}_{2}, \mathrm{c}_{1}, \mathrm{c}_{2}\right)-\mathrm{w}_{\mathrm{I}}{ }^{\mathrm{NP}}\left(\mathrm{d}_{1}, \mathrm{~d}_{2}, \mathrm{c}_{1}, \mathrm{c}_{2}\right)$. For notational simplicity we refer to this wage difference as $\zeta_{\mathrm{I}}\left(\mathrm{c}_{2}\right)$, since we are interested in varying $\mathrm{c}_{2}$. Thus $\zeta_{\mathrm{I}}\left(c_{2}\right)$ represents the wage change associated with promotions of Invisibles. In a similar vein we denote the wage change associated with the promotion of a Visible as $\zeta_{\mathrm{V}}\left(\mathrm{c}_{2}\right)$. That is, $\zeta_{\mathrm{V}}\left(\mathrm{c}_{2}\right)=\mathrm{w}_{\mathrm{V}}{ }^{\mathrm{P}}\left(\mathrm{d}_{1}, \mathrm{~d}_{2}, \mathrm{c}_{1}, \mathrm{c}_{2}\right)-\mathrm{w}_{\mathrm{V}}{ }^{\mathrm{NP}}\left(\mathrm{d}_{1}, \mathrm{~d}_{2}, \mathrm{c}_{1}, \mathrm{c}_{2}\right)$, where $\mathrm{w}_{\mathrm{V}}^{\mathrm{P}}$ denotes the 
average wage of promoted Visibles and $\mathrm{w}_{\mathrm{V}}{ }^{\mathrm{NP}}$ denotes the average wage of Visibles who are not promoted.

Testable Implication 3: Holding constant worker performance in Job 1, $\zeta_{\mathrm{I}}\left(\mathrm{c}_{2}\right)>\zeta_{\mathrm{V}}\left(\mathrm{c}_{2}\right)$.

This says that the wage change associated with promotion of an Invisible is higher than that of a Visible. In effect, the Invisible who is promoted is paid the average wage between the ability levels $\eta^{*}$ and $\eta_{\mathrm{H}}$, whereas the average Visible who is promoted corresponds to the supports $\eta^{\prime}$ and $\eta_{H}$. The result follows, since $\eta^{\prime}<\eta^{*}$.

Finally, define $\zeta\left(c_{2}\right)=\zeta_{\mathrm{I}}\left(\mathrm{c}_{2}\right)-\zeta_{\mathrm{V}}\left(\mathrm{c}_{2}\right)$. Testable implication 4 concerns how this difference varies with the degree of task variability across hierarchical levels.

Testable Implication 4: Holding constant worker performance in Job 1, consider two different job hierarchies with parameters $\overline{c_{2}}$ and $\overline{\overline{c_{2}}}$, such that, $\overline{c_{2}}<\overline{\overline{c_{2}}}$. Then $\zeta\left(\overline{\overline{c_{2}}}\right)<$ $\zeta\left(\overline{c_{2}}\right)$, i.e., when task variability across the two jobs is greater the wage increase attached to promotion becomes more similar for Invisibles and Visibles. (Proof in Appendix A)

The logic behind this is related to Testable Implication 2. Outside employers bid for workers competitively. When $c_{2}-c_{1}$ is low the inefficiency in promotion decisions is higher and the outside bids account for that. Hence, if a worker is promoted in such a regime then the outside employers correctly perceive the worker to be of higher ability than in a regime where $c_{2}-c_{1}$ is higher, implying the allocation of workers is more correct. The greater the degree of variability in tasks across hierarchical levels, the closer is the situation to the case of publicly-observable output (i.e. the case of Visibles), which in turn implies that inefficiency in job assignments diminishes, thereby reducing the amount by which Invisibles get larger wage increments when promoted.

Finally, we note that there is also a fifth implication that is potentially testable if measures of on-the-job human capital investment are available, though no such measures are available in our data. The fifth testable implication would say that, holding constant worker performance in Job 1, if the job hierarchies are such that tasks are similar in the 
job ladders, then Visibles invest in human capital whereas Invisibles do not invest. This implication follows from Propositions 1 and 2. If $c_{2}<c_{2}{ }^{*}$, Proposition 2 states that none of the Invisibles invest, whereas Proposition 1 states that all Visibles invest even when $c_{2}$ is small.

\section{DATA AND VARIABLE DEFINITIONS}

Our primary dataset consists of the complete set of personnel records for all workers hired between January 1, 1989 and December 31, 1994 in a large U.S. firm (18,334 workers in total). ${ }^{22}$ The firm is based in the Midwest but has establishments nationwide, is vertically integrated, and has divisions in health care, finance, research and development, manufacturing, sales, legal affairs, operations and distributions, and marketing. During the last two decades the firm has had several mergers and acquisitions. Gibbs and Hendricks (2004) compared the sales, number of employees, assets, market value, CEO compensation, salary structure, and yearly salary increases in this firm with the corresponding variables for other firms in the same industry, using data from the U.S. Bureau of Labor Statistics and the ExecuComp database. Their comparison suggests that the firm is representative of large U.S. firms in that industry.

The data include information on worker race, gender, age, marital status, disability status, tenure with the firm, tenure with the organizational unit, geographic location (both zip code and a building identifier), promotion and job-change history, performance rating, job title, and "functional area" from the following list: Executive Management, Business Affairs, Administrative, Human Resources, Financial Development, Finance, Regulatory Quality Assurance, Legal, Government Affairs, Public Affairs, Marketing, Operations/Distributions, Manufacturing, Sales Representatives, Sales Management, Research and Development, Electronic Data Processing, Health Care, Product Services, Intern, Customer Operations, and Scientific Affairs. Dates of promotion are recorded in the data. The firm defines a promotion as a job change to a higher job level. As noted by Gibbs and Hendricks, it is not possible to infer the firm's job hierarchy from the data, since there are over 4000 categorical job titles that reveal little about relative levels. We observe when the firm claims a

${ }^{22}$ To preserve confidentiality, we cannot disclose the name of the firm. 
promotion occurred, and that is our definition of promotion. Subjective performance evaluations by supervisors are available for workers periodically during their tenure with the firm, and these are based on a "DOGNUT" scale: "Distinguished", "Outstanding", "Good", "Needs Improvement", "Unsatisfactory”, and "Too New to Evaluate".

Each time a worker experiences an "incident", such as a job change or a change in pay, he receives a new record in the data. The entire sample consists of 18,334 workers and 89,793 worker-incidents. We organize the personnel data into worker-months. The performance and wage variables require special coding. When a performance rating was observed concurrently with a promotion or demotion (which happened often) we assumed that the rating pertained to the pre-promotion (or demotion) job. We thus filled in this rating backwards in time for each month until we hit another performance rating, or a level change (i.e. another promotion or demotion), or the hiring date. We did the same thing (backward filling) for performance ratings that were observed without a promotion or demotion. Then, wherever it was possible without overwriting our backward filling of performance ratings, we filled in performance ratings forward in time until we hit another performance rating, or a level change, or a separation from the firm. We took the same approach for wages, though in this case when filling wages in forwards or backwards in time we stopped only for a job level change, another reported wage, a new hire, or a separation from the firm (but not a performance rating).

\section{National Compensation Survey (NCS)}

Since the personnel data contain no information on the degree of task variability across hierarchical levels, we turn to the National Compensation Survey (NCS) for this complementary information. The NCS is a restricted-use survey conducted by the Bureau of Labor Statistics annually since 1997 to measure earnings and benefits by occupation and work level. The sample for the NCS is selected in three stages. First, 154 representative metropolitan and non-metropolitan areas are selected. Within these areas, sample establishments are selected, with larger establishments being more likely to be selected. All industries except agriculture, the federal government and private households are included. Finally, within each establishment, a number of jobs are selected, with more populated job titles having a higher probability of selection. The 
number of jobs selected depends upon the size of the establishment, with a maximum of twenty jobs selected. No demographic information is obtained about the worker. This sampling framework results in approximately 20,000 establishments and 137,000 jobs in 1999, the year we use. The information relevant to task variability across hierarchical levels comes from a set of ten "leveling factors" describing the nature of the work. This information is collected by field economists who visit each establishment, either via interviews with the designated respondent or from formal written job descriptions. The ten leveling factors (along with the ranges for the Likert scales on which they are measured) are: 1. knowledge (1-9); 2. supervision received (1-5); 3. guidelines (1-5); 4. complexity (1-6); 5. scope and effect (1-6); 6. personal contacts (1-4); 7. purpose of contacts (1-4); 8. physical demands (1-3); 9. work environment (1-3); 10. Supervisory duties (1-5). ${ }^{23}$ From these leveling factors we create a single index of within-occupation task variability across hierarchical levels, as explained in the next section. Table $2 \mathrm{a}$ displays descriptive statistics for the variables used in our analysis, and Table $2 \mathrm{~b}$ displays promotion frequencies by worker characteristics.

\section{EMPIRICAL ANALYSIS}

Recall that Testable Implications 2 and 4 concern the implications of varying the parameter $c_{2}$, which we interpret as changing the degree to which tasks vary across levels of the job hierarchy. Since the personnel data contain no information on job characteristics, to address those two testable implications we draw on supplementary information from the NCS. However, the information on job characteristics in the NCS is recorded (for each establishment) at the level of occupations, whereas in the personnel data we observe job titles and functional areas but not occupations. Thus, to make relevant comparisons between the two data sets, for each job in the personnel records we must infer its occupation using the detailed job title and other information in the personnel record (See Appendix B for details).

For addressing Testable Implications 1 and 2, since the minimum output threshold required for promotion is unobserved by the econometrician, we restate the testable implications in terms of the observed data on promotions, worker performance, and

${ }^{23}$ For more detailed descriptions of these leveling factors see U.S. Department of Labor, BLS (1996). 
worker characteristics. As in the theoretical model, we use the subscript ijt to index worker $\mathrm{i}$ in Job $\mathrm{j}$ (where $\mathrm{j}=1$ is the pre-promotion job and $\mathrm{j}=2$ is the post-promotion job) in period t, where a period is a month in the empirical model. Let Nonwhite ${ }_{i}$ be a dummy variable equaling 1 if worker i is black, Hispanic, Asian, or "other nonwhite" and 0 if the worker is white. Let Promotion $_{i j t}$ be a dummy variable equaling 1 if worker i is promoted out of job j in month $\mathrm{t}$, and 0 otherwise, let Performance ${ }_{i j t}$ be worker i's performance rating in job $\mathrm{j}$ in month $\mathrm{t}$, and let $\mathbf{X}_{\mathrm{ijt}}$ be a vector of controls (including gender, age, age squared, tenure at the firm, tenure at the firm squared, tenure in the job level, tenure in the job level squared, marital status as of the hiring date, part time status, and educational attainment). We specify the following equations for the output of worker $\mathrm{i}$ in Job 1 in the first period (5.1) and the minimum output this worker must produce in Job 1 to be promoted (5.2):

$\mathrm{y}_{\mathrm{i} 11}=\mathrm{f}\left(\right.$ Performance $\left._{\mathrm{i} 11}\right)+\mathrm{e}_{\mathrm{i} 11}$

$\mathrm{y}_{\mathrm{i} 11}^{\mathrm{P}}=\gamma_{0}+\gamma_{1}$ Nonwhite $_{\mathrm{i}}+\mathbf{X}_{\mathrm{i} 11} \boldsymbol{\lambda}+\mathrm{u}_{\mathrm{i} 11}$

where $\mathrm{f}$ is a monotonically increasing function, and $\mathrm{e}_{\mathrm{i} 11}$ and $\mathrm{u}_{\mathrm{i} 11}$ are stochastic, mean-zero disturbances. A promotion from Job 1 to Job 2 occurs if worker i produces a first-period output in Job 1 that exceeds the minimum output threshold, so that:

$$
\begin{aligned}
\text { Promotion }_{i 11} & =1 \text { if } \mathrm{y}_{\mathrm{i} 11}-\mathrm{y}_{\mathrm{i} 11}{ }^{\mathrm{P}} \geq 0 \\
& =0 \text { otherwise }
\end{aligned}
$$

Recall that in the theoretical model $\xi$ denotes $\mathrm{y}_{\mathrm{I}}^{\mathrm{P}}-\mathrm{y}_{\mathrm{V}}{ }^{\mathrm{P}}$, which is the difference between Invisibles and Visibles in the minimum output threshold required for promotion. The empirical counterpart of $\xi$ is the difference between the predicted value of (5.2) when Nonwhite $_{i}$ is evaluated at 1 and the predicted value of (5.2) when Nonwhite $e_{i}$ is evaluated at 0 . Since Testable Implication 1 implies that $\xi$ is positive, the corresponding prediction in the empirical model is that $\gamma_{1}$ is positive.

Substituting (5.1) and (5.2) into (5.3), and assuming that $\mathrm{f}$ is linear so that $\mathrm{y}_{\mathrm{i} 11}=\alpha_{0}$ $+\alpha_{1}$ Performance $_{\mathrm{i} 11}+\mathrm{e}_{\mathrm{i} 11}$ with $\alpha_{1}>0$, yields the following expression:

$$
\begin{aligned}
\text { Promotion }_{\mathrm{i} 11} & =1 \text { if } \beta_{0}+\beta_{1} \text { Nonwhite }_{\mathrm{i}}+\beta_{2} \text { Performance }_{\mathrm{i} 11}+\mathbf{X}_{\mathrm{i} 11} \boldsymbol{\delta} \geq \varepsilon_{\mathrm{i} 11} \\
& =0 \text { otherwise }
\end{aligned}
$$


where $\varepsilon_{i 11}=u_{i 11}-e_{i 11}, \beta_{0}=\alpha_{0}-\gamma_{0}, \beta_{1}=-\gamma_{1}, \beta_{2}=\alpha_{1}$, and $\boldsymbol{\delta}=-\lambda$. Assuming that $\varepsilon_{i 11}$ has the standard normal distribution, the promotion rule is described by the following probit model where $\Phi$ denotes the standard normal cdf:

$\operatorname{Prob}\left(\right.$ Promotion $\left._{\mathrm{i} 11}=1\right)=\boldsymbol{\Phi}\left(\beta_{0}+\beta_{1}\right.$ Nonwhite $_{\mathrm{i}}+\beta_{2}$ Performance $\left._{\mathrm{i} 11}+\mathbf{X}_{\mathrm{i} 11} \boldsymbol{\delta}\right)$

Thus, Testable Implication 1 implies that $\beta_{1}$ is negative.

Results from probit estimation of (5.5), for various configurations of control variables $\mathbf{X}_{\mathrm{i} 11}$, are reported in Table 3. A negative estimate for $\beta_{1}$ is found in all specifications, and statistical significance at the ten percent level (on a one-tailed test) is achieved in each specification. ${ }^{24}$ Note that the coefficient of the gender dummy is statistically insignificant in each specification, confirming our earlier statement that gender differences in promotion appear not to exist in this firm. Due to large numbers of missing values in the educational attainment and performance variables, the sample sizes shrink considerably in the specifications that include these variables. However, when these variables are included they reveal that the probability of promotion increases with educational attainment and with the performance rating in the pre-promotion job. Both of these results were also found in DeVaro and Waldman (2006) using personnel data from the firm in the financial services industry that was first analyzed by Baker, Gibbs, and Holmstrom (1994). Since the estimated $\beta_{1}$ is relatively insensitive to the inclusion of both these controls, and their inclusion reduces precision on the parameters of interest by significantly reducing the sample size, we do not include these controls in the subsequent models we estimate.

To address Testable Implication 2, we begin by constructing a new variable called Variability $_{j}$ using NCS data. This variable is designed to proxy for the degree of task variability across hierarchical levels in occupation $\mathrm{j}$. To do this, we first normalize these leveling factors to zero-one, to take into account the varying ranges of responses. We then add the responses to create a single task index. Our variability measure is the within-occupation coefficient of variation of this index, using three-digit occupations. Note that this measure captures task variability within occupations. As stated in Appendix B, less than eight percent of promotions in our data involve a change in

\footnotetext{
${ }^{24}$ Throughout the analysis, when directional hypotheses are implied by the theory we use one-tailed hypothesis tests in assessing statistical significance.
} 
occupation, though for such promotions we would expect the resulting change in tasks to be larger than for within-occupation promotions, and a different measure of variability would be required.

Note that to assign to each worker-month in the personnel data a particular value of this variability index, we need to know the occupation for that worker-month. As described in Appendix B, we infer the three-digit occupation in the personnel data using information on the job title and functional area, thereby bridging the NCS and personnel data. We then augment the probit model of (5.5) as follows:

$$
\begin{array}{r}
\operatorname{Prob}\left(\text { Promotion }_{\mathrm{i} 11}=1\right)=\boldsymbol{\Phi}\left(\beta_{0}+\beta_{1} \text { Nonwhite }_{\mathrm{i}}+\beta_{2} \text { Performance }_{\mathrm{i} 11}+\beta_{3} \text { Variability }_{\mathrm{j}}+\right. \\
\left.\beta_{4}\left(\text { Variability }_{\mathrm{j}} \times \text { Nonwhite }_{i}\right)+\mathbf{X}_{\mathrm{i} 11} \mathbf{\delta}\right)
\end{array}
$$

Testable Implication 2 implies $\beta_{4}>0$, meaning the disadvantage of nonwhites relative to whites in promotion probabilities (i.e. $\beta_{1}<0$ ) is mitigated when tasks are more variable across hierarchical levels.

Results from probit estimation of (5.6), for various configurations of control variables $\mathbf{X}_{\mathrm{i} 11}$, are reported in Table 4. The results in Column 1, omitting controls, reveal support for the theoretical prediction (a negative coefficient on Nonwhite and a positive coefficient on the interaction of Nonwhite and Variability). Note that the estimated main effect of Variability is negative. As explained in Section III, this result is consistent with reducing the parameter $d_{2}$ in the theoretical model (simultaneously with the increase in the parameter $c_{2}$ ) by enough so that the ability thresholds $\eta^{\prime}$ and $\eta^{*}$ increase. Column 2 reveals that the results are insensitive to the inclusion of our baseline controls. However, in unreported tests we found that if we include the educational attainment and/or prepromotion job performance controls, statistical significance is lost on the parameters of interest. Columns 3 and 4 add a control for the square of Variability to the specifications in columns 1 and 2, respectively. We find that the theoretical predictions are still supported in the presence of the quadratic Variability control, though an interesting nonlinearity emerges in the marginal effect of Variability on promotion probability. While the coefficient on Variability remains negative, the coefficient on the square of Variability is positive, significant, and large enough in magnitude so that for sufficiently large values of Variability the sign of the marginal effect of Variability switches from negative to positive. 
To address Testable Implication 3, we estimate the following regression:

$\Delta \ln \mathrm{W}_{\mathrm{it}}=\pi_{0}+\pi_{1}$ Promotion $_{\mathrm{ijt}}+\pi_{2}$ Nonwhite $_{\mathrm{i}}+\pi_{3}\left(\right.$ Promotion $_{\mathrm{i}} \times$ Nonwhite $\left._{\mathrm{ijt}}\right)+\mathbf{X}_{\mathrm{i} 11} \boldsymbol{\rho}+\boldsymbol{\varepsilon}_{\mathrm{it}}$

where $\Delta \ln \mathrm{W}_{\mathrm{it}} \equiv \ln \mathrm{W}_{\mathrm{it}}-\ln \mathrm{W}_{\mathrm{it}-1}$, and $\mathrm{W}_{\mathrm{it}}$ is worker i's salary in the post-promotion job

while $\mathrm{W}_{\mathrm{it}-1}$ is worker i's most-recently-recorded salary in the pre-promotion job. Testable Implication 3 implies $\boldsymbol{\pi}_{2}+\boldsymbol{\pi}_{3}>0$, so that promoted Invisibles experience higher wage increases than promoted Visibles. Table 5 reports results for OLS estimation of regression (5.7). Column 1 of Table 5 reports the specification that excludes the baseline control variables from (5.7), and the results support the theoretical prediction that $\boldsymbol{\pi}_{2}+\boldsymbol{\pi}_{3}$ $>0$. The result persists even in the presence of the baseline controls (Column 2) and the baseline controls plus performance controls (Column 4). Although the theoretical result is unsupported in the two models that include controls for educational attainment (Columns 3 and 5), it should be noted that the sample size is dramatically reduced in the presence of education controls and that the education coefficients are never statistically significant.

To address Testable Implication 4 , for the subsample for which Promotion $_{\mathrm{it}}=1$ we estimate the following augmented version of regression (5.7): 


\begin{abstract}
$\Delta \ln \mathrm{W}_{\mathrm{it}}=\pi_{0}+\pi_{1}$ Promotion $_{\mathrm{ijt}}+\pi_{2}$ Nonwhite $_{\mathrm{i}}+\pi_{3}\left(\right.$ Promotion $_{\mathrm{ijt}} \times$ Nonwhite $\left._{\mathrm{i}}\right)+$ $\pi_{4}$ Variability $_{j}+\pi_{5}\left(\right.$ Promotion $_{\mathrm{ijt}} \times$ Variability $\left._{\mathrm{j}}\right)+\pi_{6}\left(\right.$ Nonwhite $_{\mathrm{i}} \times$ Variability $\left._{\mathrm{j}}\right)+$ $\pi_{7}\left(\right.$ Promotion $_{\mathrm{ijt}} \times$ Nonwhite $_{\mathrm{i}} \times$ Variability $\left._{\mathrm{j}}\right)+\mathbf{X}_{\mathrm{i} 11} \boldsymbol{\rho}+\boldsymbol{\varepsilon}_{\mathrm{it}}$

In this specification, Testable Implication 4 implies $\pi_{4}+\pi_{7}<0$. Also, Testable Implication 3 in this more general specification than (5.7) implies $\pi_{2}+\pi_{3}+\left(\pi_{4}+\right.$ $\left.\pi_{7}\right)_{\text {Variability }_{j}}>0$. Results from OLS regression of (5.8) are displayed in Table 6, revealing that Testable Implication 4 is not supported empirically. Across all specifications, $\pi_{4}+\pi_{7}$ is positive rather than negative, since the estimated coefficient of the 3-way interaction is positive rather than negative as our theory predicts. In the following section we discuss a potential explanation for the lack of empirical support for our Testable Implication $4 .^{25}$

\title{
VI. DISCUSSION AND CONCLUSION
}

\footnotetext{
${ }^{25}$ A potential reason for the weak results in the wage-growth regressions is the way in which we have imputed wages when missing wages occur; in the next draft we plan to linearly impute the wages between actual observed wages. Also, a potential problem with the wage growth regression is that the promotions of nonwhites may differ from those of whites in unmeasured ways (in particular by occupation). The measured effect of nonwhite status in the regression might also reflect the effect of being promoted into or out of the types of occupations in which nonwhites are more likely to be employed. However, including a full set of occupation controls in the model is not feasible, since then the effect of task variability (the primary theoretical effect of interest) cannot be identified, since it is a linear combination of 3-digit occupation dummies.
} 
Building on work by Waldman (1984) and Milgrom and Oster (1987), we have proposed a new theory that potentially explains racial and gender discrimination in promotions as well as how and why such discrimination varies by the nature of the job hierarchy. Four testable implications emerge from our theoretical model, all of which assume performance in the pre-promotion job is held constant: 1) promotion probabilities are lower for Invisibles than Visibles; 2) this gap in promotion probabilities between Invisibles and Visibles becomes smaller when job tasks differ significantly across hierarchical levels; 3) wage increases attached to promotion should be larger for Invisibles than Visibles; 4) the result in (3) should be most pronounced in jobs that are part of hierarchies characterized by a low degree of task variability across levels. While the first testable implication is also consistent with other theoretical models of discrimination in promotions (e.g. Lazear and Rosen 1990 or Athey et al. 2000), the others are distinguishing features of our model since they follow from the signaling framework combined with the degree to which tasks vary across hierarchical levels. Nothing in the models of Lazear and Rosen or Athey et al. should give rise to differences in outcomes arising from differences in task variability across hierarchical levels.

While our empirical analysis of a single firm focused only on racial differences in promotions, our theory could be used in future tests using other datasets to address discrimination by gender. In our empirical analysis, we find clear support for Testable Implications 1 and 2 concerning promotion probabilities. That is, nonwhites have lower promotion probabilities than whites, and this racial difference in promotion probabilities is mitigated in hierarchies with substantial variability in tasks across levels. The empirical evidence is mixed for the theory's predictions regarding the wage growth attached to promotions. Testable Implication 3 is supported in that promoted nonwhites experience greater wage increases than promoted whites. But Testable Implication 4 (that the racial difference in wage growth attached to promotions is mitigated when task variability is high) is empirically unsupported.

There is an omitted feature of our theoretical model that could potentially affect the empirical analysis of the previous section, making it difficult to find empirical support for our testable implications even if job-assignment signaling of the type we study is present in the firm we analyze. Our model, like most other models of job assignment 
signaling, does not account for the role of promotions in creating worker incentives to exert effort, even though recent empirical evidence suggests that promotion tournaments do have incentive effects (e.g. Audas, Barmby, and Treble (2004), DeVaro (2006a, 2006b)). The presence of tournament-style incentives from promotions would make the implications of our model harder to detect in the data. The logic for this is based on the analysis of Zabojnik and Bernhardt (2001), in which the wage spread between job levels in a promotion tournament is generated by the signaling role of promotions rather than strategically chosen by the employer to elicit the optimal level of worker effort. Consider Testable Implication 1, stating that the employer is less likely to promote Invisibles than Visibles with the same pre-promotion job performance. This effectively handicaps Invisibles in the promotion tournament, depressing incentives both for Invisibles (who do not exert as much effort since they are unlikely to win) and for Visibles (who do not exert as much effort since they are likely to win easily). From the employer's perspective, this prospect of depressed incentives is an additional cost of under-promoting Invisibles that our model ignores, and it should mitigate Testable Implication 1, making it harder to identify in the data.

Next consider Testable Implication 2, stating that the under-promotion of Invisibles occurs to a greater extent when tasks are similar across hierarchical levels. In such job hierarchies, the tradeoff of incentives and optimal assignment that the employer faces when making promotion decisions disappears. That is, the decision that is best from an incentives perspective (promoting the worker with the best performance in Job 1) is also best from an assignment perspective. In a job hierarchy with similar tasks across hierarchical levels, our Testable Implication 2 states that the employer should be less likely to promote an Invisible with a high performance in Job 1. This failure to promote imposes a large cost in terms of incentives. In contrast, in a hierarchy where tasks are very different across levels, the incentives cost of under-promoting high-performing Invisibles is lower since the Invisibles with high performances in Job 1 do not necessarily expect to be promoted to Job 2 (given that the jobs are totally different). Thus, the presence of incentives should also mitigate Testable Implications 2, 3, and 4, rendering them harder to support empirically. This is a potential reason for the lack of empirical support for Testable Implication 4. 
To our knowledge, our study is the first to try to measure empirically the degree of task variability across levels of a promotional hierarchy. We think that such a measure is potentially useful in a range of applications beyond the particular theory we address in this paper. A number of theoretical models in the promotions literature either explicitly incorporate the degree of task variability across hierarchical levels or have predictions that should logically vary by this measure. Thus, our measures should be useful in future work that attempts to address other theories with new data. One example of such a study is Ghosh and Waldman (2006).

Finally, we see our theoretical model as offering a potential explanation for why the degree of discrimination in promotions by race or gender might vary by occupation. Previous theoretical research on discrimination in the workplace has investigated the possible reasons for discrimination and the potential ways in which the problem can be eradicated. An issue that has not been addressed in the literature is the possibility that discrimination in promotions may vary across occupations due to inherent differences in the degree to which job tasks differ across levels of job hierarchies that exist primarily within occupations. Our analysis suggests that the nature of the job tasks across hierarchical levels is potentially important in explaining differences in discrimination across occupations. Some policy implications naturally arise from this. For example, it might be that optimal affirmative action policies should vary by occupation as a result of the inherent differences in the task hierarchies across occupations. The force of such policy recommendations obviously rests on corroborating future research using data beyond the particular firm in this case study. 


\section{REFERENCES}

Acosta, Pablo (2006), "Promotions, State Dependence and Intrafirm Job Mobility: Insiders Versus New Hires.” Working paper, University of Illinois.

Anandarajan, Asokan, et al. "Gender, Ethnicity, and Demographic Factors Influencing Promotions to Managers for Auditors: An Empirical Analysis". Advances in Public Interest Accounting, vol. 9. 2002.

Arrow, K.J., "The Theory of Discrimination," in O. Ashenfelter and A. Rees, eds. Discrimination in Labor Markets, Princeton, NJ: Princeton University Press, 1973, 3-33.

Athey, S., C. Avery and P. Zemsky., "Mentoring and Diversity," American Economic Review, 2000, Vol 90 (4), 765-786.

Audas, Rick, Tim Barmby, and John Treble. "Luck, Effort, and Reward in an Organizational Hierarchy." Journal of Labor Economics, Vol. 22 (2004), 379395.

Baker, G., M. Gibbs, and B. Holmstrom, "The Internal Economics of the Firm: Evidence from Personnel Data," Quarterly Journal of Economics, 109, 1994b, 921-955.

Baldwin, J. Norman. "The Promotion Record of the United States Army: Glass Ceilings in the Officer Corps". Public Administration Review. 56:2, March-April 1996.

Bamberger, Peter, Michael Admati-Dvir, and Gedaliahu Harel, "Gender-Based Wage and Promotion Discrimination in Israeli High-Technology Firms: Do Unions Make a Difference?" Academy of Management Journal 1995, Vol. 38, No. 6, 1744-1761.

Becker, G., The Economics of Discrimination, (Chicago: University of Chicago Press, 1957).

Bellemore, Fred. "Racial and Ethnic Employment Discrimination: Promotion in Major League Baseball”. Journal of Sports Economics. 2:4, November 2001.

Belzil, C. and M. Bognanno, "The Promotion Dynamics of American Executives," mimeo, Temple University, 2005.

Bernhardt, D., "Strategic Promotion and Compensation," Review of Economic Studies, 62, 1995, 315-339.

Bernheim, B.D., B. Peleg and M. Whinston. 1987, "Coalition- Proof Nash Equilibria I. Concepts", Journal of Economic Theory, XLII: 1-12. 
Blau, Francine D., and Jed DeVaro. "New Evidence on Gender Differences in Promotion Rates: An Empirical Analysis of a Cross Section of Establishments." Industrial Relations, Volume 46, Number 3, July 2007, 511 - 550.

Booth, Alison L., Marco Francesconi, and Jeff Frank. "A Sticky Floors Model of Promotion, Pay, and Gender.” European Economic Review 47 (2003) 295-322.

Cabral, Robert, Marianne A. Ferber, and Carole Green. 1981. "Men and Women in Fiduciary Institutions: A Study of Sex Differences in Career Development," Review of Economics and Statistics 63 (November) 573-580.

Cannings, Kathy. 1988. "Managerial Promotion: The Effects of Socialization, Specialization, and Gender." Industrial and Labor Relations Review 42 (October): 77-88.

Chang, C. and Y. Wang, "Human Capital Investment Under Asymmetric Information: The Pigovian Conjecture Revisited," Journal of Labor Economics, 14, 1996, 505519.

Coate, S., and G. Loury, "Will Affirmative Action Policies Eliminate Negative Stereotypes?," American Economic Review, December 1993, 83, 1220-1240.

Cobb-Clark, Deborah A., "Getting Ahead: The Determinants of and Payoffs to Internal Promotion for Young U.S. Men and Women." In Solomon W. Polachek, ed., Worker Wellbeing in a Changing Labor Market, Research in Labor Economics, Volume 20, pages 339-372, (2001).

DeAngelis, C, "Women in Academic Medicine: New Insights, Some Sad News," New England Journal of Medicine, 2000, 342(6), Feb 10.

DeVaro, Jed (2006a). "Strategic Promotion Tournaments and Worker Performance," Strategic Management Journal, Volume 27, Issue 8, August 2006, 721-740.

DeVaro, Jed (2006b). "Internal Promotion Competitions in Firms," RAND Journal of Economics, Volume 27, Number 3, Autumn 2006.

DeVaro, Jed, and Michael Waldman. "The Signaling Role of Promotions: Further Theory and Empirical Evidence.” Working paper, Cornell University, 2006.

Doiron, D., "Layoffs as Signals: The Canadian Evidence," Canadian Journal of Economics, 28, 1995, 899-913.

Eberts, Randall W., and Joe A. Stone. "Male-Female Differences in Promotions: EEO in Public Education," Journal of Human Resources (1985).

Gerhart, Barry A., and George T. Milkovich. 1989. "Salaries, Salary Growth, and 
Promotions of Men and Women in a Large, Private Firm" In Pay Equity:

Empirical Inquiries, edited by Robert T. Michael, Heidi I. Hartmann, and Brigid O'Farrell, pp.23-43. Washington, DC: National Academy Press.

Ghosh, S., and M. Waldman, "Standard Promotion Practices versus Up-or-Out Contracts," Mimeo, Cornell University, 2006.

Gibbons, R., and L. Katz, "Layoffs and Lemons," Journal of Labor Economics, 9, 1991, 351-380.

Gibbons, R. and M. Waldman, "A Theory of Wage and Promotion Dynamics Inside Firms," Quarterly Journal of Economics, 114, 1999, 1321-1358.

Gibbs, Michael and Hendricks, Wallace. 2004. "Do Formal Salary Systems Really Matter?", Industrial and Labor Relations Review, Vol. 56, No.1 (October), pp. 71-93.

Ginther, D.K., and K.J. Hayes, "Gender Differences in Salary and Promotion in the Humanities", American Economic Review Papers and Proceedings, 1999, 89 (2), 397-402.

Ginther, D.K., and K.J. Hayes. "Gender Differences in Salary and Promotion for Faculty in the Humanities 1977-95." Journal of Human Resources, 2003, 38(1):34-73.

Giulano, Laura, David I. Levine, and Jonathan Leonard. "Do Race, Gender, and Age Differences Affect Manager-Employee Relations? An Analysis of Quits, Dismissals, and Promotions at a Large Retail Firm.” Working paper (2005).

Gjerde, Kathy A. Paulson. "The Existence of Gender-Specific Promotion Standards in the U.S." Managerial and Decision Economics 23: 447-459 (2002).

Golan, L., "Counteroffers and Efficiency in Labor Markets with Asymmetric Information," Journal of Labor Economics, 23, 2005, 373-393.

Gorman, E, Gender and Organizational Selection Decisions: Evidence from Law Firms. Cambridge, MA: Unpublished doctoral dissertation, 2001.

Greenwald, B., "Adverse Selection in the Labor Market," Review of Economic Studies, 53, 1986, 325-347.

Grund, C., "Stigma Effects of Layoffs? Evidence from German Micro-Data," Economics Letters, 64, 1999, 241-247.

Hersch, John and W. Kip Viscusi, "Gender Differences in Promotions and Wages," Industrial Relations, Vol. 35, No. 4 (October 1996). 
Harsanyi, J. "Games with Incomplete Information Played by 'Bayesian' Players”, Parts I, II, III. Management Science, Vol 14, 1967, 1968, 1969, 159-182, 320-324, 486502.

Jones, David R., and Gerald H. Makepeace. "Equal Worth, Equal Opportunities: Pay and Promotion in an Internal Labor Market." The Economic Journal, 106: March 1996.

Kahn, C., and G. Huberman. "Two-sided Uncertainty and "Up-or-out" Contracts" Journal of Labor Economics, Vol 6, No 4, 1988, 423-444.

Killingsworth, Mark and Cordelia Reimers. "Race, Rankings, Promotions, and Pay at a Federal Facility: A Logit Analysis". Industrial and Labor Relations Review. 37:1, October 1983.

Landau, Jacqueline. "The Relationship of Race and Gender to Managers' Ratings of Promotion Potential”. Journal of Organizational Behavior. 16:4, July 1995.

Lazear, E., "Raids and Offer Matching," in R. Ehrenberg, ed., Research in Labor Economics, Vol. 8, JAI Press: Greenwich, CT, 1986, 141-165.

Lazear, Edward P., and Sherwin Rosen. "Male-Female Wage Differentials in Job Ladders," Journal of Labor Economics, 1990, vol. 8, no. 1, S106-S123.

Lewis, Gregory B. (1986). "Gender and Promotions: Promotion Chances of White Men and Women in Federal White-Collar Employment." Journal of Human Resources 21 (Summer) 406-419.

Lundberg, S.J., and R. Startz, "Private Discrimination and Social Intervention in Competitive Labor Markets," American Economic Review, LXXIII 1983, 340347.

MacLeod, W.B. and J. Malcomson, "Reputation and Hierarchy in Dynamic Models of Employment," Journal of Political Economy, 96, 1988, 832-854.

Manning, L and V. Wight., Women in the Military: Where They Stand, 2000, $3^{\text {rd }}$ edition. Washington D.C: Women's Research and Education Institute.

McCue, Kristin, "Promotions and Wage Growth" Journal of Labor Economics, 1996.

Mellor, Jennifer, and Elizabeth Paulin. "The effects of Gender and Race on Salary Growth: The Role of Occupational Structure in a Service Sector Firm". Eastern Economic Journal. 21:3. Summer 1995.

Milgrom, P., and S. Oster, "Job Discrimination, Market Forces, and the Invisibility Hypothesis," Quarterly Journal of Economics, 102, 1987, 453-476. 
Milgrom, P. and J. Roberts. Limit Pricing and Entry Under Incomplete Information: An Equilibrium Analysis, Econometrica, Vol. 50 (March 1982), pp. 443-459.

Mishra, A., "A Theory of Discrimination Based on Signaling and Strategic Information Acquisition," Department of Economics Working Paper, University of Dundee, 2003.

O'Flaherty, Brendan \& Siow, Aloysius, 1995. "Up-or-out Rules in the Market for Lawyers," Journal of Labor Economics, Vol. 13 (4) pp. 709-35.

Olson, Craig A., and Brian E. Becker. 1983. "Sex Discrimination in the Promotion Process." Industrial and Labor Relations Review 36 (July) 624-641.

Owan, H., "Promotion, Turnover, Earnings, and Firm-Sponsored Training," Journal of Labor Economics, 22, 2004, 955-978.

Padavic, I., and B. Reskin, Women and Men At Work, $2^{\text {nd }}$ Edition, 2003.

Paulin, Elizabeth and Jennifer Mellor. "Gender, Race, and Promotions within a Private -Sector Firm”. Industrial Relations. 35:2, April 1996.

Pekkarinen, T, and J. Vartianen, "Gender Differences in Job Assignment and Promotion in a Complexity Ladder of Jobs," European University Institute, Working Paper, 2003.

Pergamit and Veum. "What Is a Promotion?". Industrial and Labor Relations Review. 52:4, July 1999.

Phelps, E.S., "The Statistical Theory of Racism and Sexism," American Economic Review, LXII 1972, 659-661.

Pinkston, J., "A Model of Asymmetric Employer Learning with Testable Implications," BLS Working Paper 365, 2004.

Powell, Gary and D. Anthony Butterfield. "Effect of Race on Promotions to Top Management in a Federal Department". The Academy of Management Journal. 40:1, February 1997.

Powell, Gary N., and D. Anthony Butterfield. "Investigating the 'Glass Ceiling' Phenomenon: An Empirical Study of Actual Promotions to Top Management," Academy of Management Journal 1994, Vol. 37, No. 1, 68-86.

Pudney, Stephen and Michael Shields. "Gender, Race, Pay and Promotion in the British Nursing Profession: Estimation of a Generalized Ordered Probit Model". Journal of Applied Econometrics. 15: 367-399 (2000a). 
Pudney, Stephen and Michael Shields. "Gender and Racial Discrimination in Pay and Promotion for NHS Nurses". Oxford Bulletin of Economics and Statistics. 62:s5, December (2000b).

Ransom, Michael, and Ronald L. Oaxaca. "Intrafirm Mobility and Sex Differences in Pay," Industrial and Labor Relations Review, Vol. 58, January 2005.

Ranson, Gillian, and William Joseph Reeves, "Gender, Earnings, and Proportions of Women: Lessons from a High-Tech Occupation," Gender and Society, Vol. 10, No. 2, April 1996.

Rhode, D.L., Unfinished Agenda: Women and the Legal profession. Chicago, IL: American Bar Association, Commission on Women in the Profession, 2001.

Ricart i Costa, J., "Managerial Task Assignment and Promotion,” Econometrica, 56, 1988, 449-466.

Sabatier, Mareva, and Myriam Carrere. "Do Female Researchers Face a Glass Ceiling in France? A Hazard Model of Promotions.” Working paper, Universite de Savoie, (2005).

Schonberg, U., "Testing for Asymmetric Employer Learning," mimeo, University of Rochester, 2004.

Spurr, S.J., "Sex Discrimination in the Legal profession: A Study of Promotion," Industrial and Labor Relations Review, Vol 43, No 4, April 1990, 406-417.

Stewart, James and Juanita Firestone. "Looking for a Few Good Men: Predicting Patterns of Retention, Promotion, and Accession of Minority and Female Officers". American Journal of Economics and Sociology. 51: 4, October 1992.

Stewart, Lea P., and William B. Gudykunst. 1982. "Differential Factors Influencing the Hierarchical Level and Number of Promotions of Males and Females Within an Organization," Academy of Management Journal 25 (September) 586-597.

Sundstrom, William. "Half a Career: Discrimination and Railroad Internal Labor Markets". Industrial Relations. 29:3, Fall 1990.

U.S. Department of Labor, Bureau of Labor Statistics (1996). Evaluating Your Firm's Jobs and Pay. Washington, DC: Division of Information Services.

Waldman, M., "Job Assignments, Signalling, and Efficiency," Rand Journal of Economics, 15, 1984, 255-267.

Waldman, M., "Up-or-Out Contracts: A Signaling Perspective," Journal of Labor Economics, 8, 1990, 230-250. 
Winter-Ebmer, Rudolf, and Josef Zweimuller. "Unequal Assignment and Unequal Promotion in Job Ladders," Journal of Labor Economics, 1997, Volume 15, No. 1, Part 1, 43-71.

Wright, Erik Olin, Janeen Baxter, and Gunn Elisabeth Birkelund. "The Gender Gap in Workplace Authority: A Cross-National Study," American Sociological Review, 1995, Vol. 60 (June: 407-435).

Zabojnik, J. and D. Bernhardt, "Corporate Tournaments, Human Capital Acquisition, and the Firm Size-Wage Relation," Review of Economic Studies, 68, 2001, 693-716. 


\section{APPENDIX A}

Proof of Lemma 1: We need to prove that $\eta^{\prime}<\eta^{*}$. Suppose not. That is, suppose $\eta^{\prime}>\eta^{*}$. Our strategy in proving this lemma will be to show a contradiction in this case. We know that $\eta^{*}=\frac{2(\alpha-\beta)\left(d_{1}-d_{2}\right)+\beta\left(c_{2} \eta_{H}-c_{1} \eta_{L}\right)}{2\left(c_{2}-c_{1}\right)(2 \alpha-\beta)}$ and $\eta^{\prime}=\left(\mathrm{d}_{1}-\mathrm{d}_{2}\right) /\left(\mathrm{c}_{2}-\mathrm{c}_{1}\right)$. If $\eta^{\prime}>\eta^{*}$, then we will get $\left(\mathrm{d}_{1}-\mathrm{d}_{2}\right) /\left(\mathrm{c}_{2}-\mathrm{c}_{1}\right)>\frac{2(\alpha-\beta)\left(d_{1}-d_{2}\right)+\beta\left(c_{2} \eta_{H}-c_{1} \eta_{L}\right)}{2\left(c_{2}-c_{1}\right)(2 \alpha-\beta)}$. This simplifies to $\left(\mathrm{d}_{1}-\mathrm{d}_{2}\right)>$ $c_{2} \eta_{\mathrm{H}}-c_{1} \eta_{\mathrm{L}}$. But from inequality (1) we know that $\left(\mathrm{d}_{1}-\mathrm{d}_{2}\right)<\mathrm{c}_{2} \eta_{\mathrm{H}}-\mathrm{c}_{1} \eta_{\mathrm{H}}$. And since $\eta_{\mathrm{H}}$ $>\eta_{\mathrm{L}}, \mathrm{c}_{2} \eta_{\mathrm{H}}-\mathrm{c}_{1} \eta_{\mathrm{L}}>\mathrm{c}_{2} \eta_{\mathrm{H}}-\mathrm{c}_{1} \eta_{\mathrm{H}}$. Hence $\left(\mathrm{d}_{1}-\mathrm{d}_{2}\right)<\mathrm{c}_{2} \eta_{\mathrm{H}}-\mathrm{c}_{1} \eta_{\mathrm{L}}$, which leads to a contradiction.

Proof of Proposition 1: We solve this backwards, that is we start from the second period. First of all, the employer follows the optimal promotion decision since information is perfect. The optimal promotion decision is given by (see page 6 in the text): The worker is assigned to job 1 if $\eta_{\mathrm{i}}<\eta^{\prime}$, and to job 2 if $\eta_{\mathrm{i}}>\eta^{\prime}$, where $\eta^{\prime}$ is the ability level at which a worker is equally productive at jobs 1 and 2 . That is, $\eta^{\prime}$ solves $\mathrm{d}_{1}+\mathrm{c}_{1} \eta_{\mathrm{i}}=\mathrm{d}_{2}+\mathrm{c}_{2} \eta_{\mathrm{i}}$, that is, $\eta^{\prime}=\left(\mathrm{d}_{1}-\mathrm{d}_{2}\right) /\left(\mathrm{c}_{2}-\mathrm{c}_{1}\right)$. The outside firms bid $\beta\left(\mathrm{d}_{2}+\mathrm{c}_{2} \eta_{\mathrm{i}}\right)$ if the worker is such that $\eta_{\mathrm{i}}>\eta^{\prime}$ or else $\beta\left(\mathrm{d}_{1}+\mathrm{c}_{1} \eta_{\mathrm{i}}\right)$ if the worker is $\eta_{\mathrm{i}}<\eta^{\prime}$. It is easy to verify than no other wage (either higher or lower than this) can be a best response for an outside firm. Now in period 1 the worker's decision to invest is by the following inequality $\beta\left[\mathrm{d}_{2}+\mathrm{c}_{2}\left(\left(\eta_{\mathrm{L}}+\eta_{\mathrm{H}}\right) / 2\right)-\left\{\mathrm{d}_{1}+\mathrm{c}_{1}\left(\left(\eta_{\mathrm{H}}+\eta_{\mathrm{L}}\right) / 2\right)\right\}\right]\left[\left\{\left(\eta_{\mathrm{H}^{-}} \eta^{*}\right) /\left(\eta_{\mathrm{H}^{-}} \eta_{\mathrm{L}}\right)\right\}\right]>\mathrm{z}$,

where he only invests if the gains from investing (the left hand side) is larger than the cost ' $z$ ' of investing. This will hold only if $\beta>\bar{\beta}$, where $\bar{\beta}$ is given by the solution of the equation $\beta\left[\mathrm{d}_{2}+\mathrm{c}_{2}\left(\left(\eta_{\mathrm{L}}+\eta_{\mathrm{H}}\right) / 2\right)-\left\{\mathrm{d}_{1}+\mathrm{c}_{1}\left(\left(\eta_{\mathrm{H}}+\eta_{\mathrm{L}}\right) / 2\right)\right\}\right]\left[\left\{\left(\eta_{\mathrm{H}^{-}} \eta^{*}\right) /\left(\eta_{\mathrm{H}^{-}} \eta_{\mathrm{L}}\right)\right\}\right]=\mathrm{z}$.

We find $\mathrm{W}^{1}$ by imposing a net expected profit of zero condition for the employer since firms are perfectly competitive.

$$
\begin{aligned}
& \mathrm{W}^{1}+\mathrm{X}^{1} \beta\left(\mathrm{d}_{2}+\mathrm{c}_{2}\left(\left(\eta_{\mathrm{H}}+\eta_{\mathrm{L}}\right) / 2\right)\right)+\left(1-\mathrm{X}^{1}\right) \beta\left(\mathrm{d}_{1}+\mathrm{c}_{1}\left(\left(\eta_{\mathrm{H}}+\eta_{\mathrm{L}}\right) / 2\right)\right)=\mathrm{d}_{1}+\mathrm{c}_{1}\left(\left(\eta_{\mathrm{L}}+\eta_{\mathrm{H}}\right) / 2\right)+\mathrm{X}^{2} \alpha\left(\mathrm{d}_{2}+\right. \\
& \left.\mathrm{c}_{2}\left(\left(\eta_{\mathrm{H}}+\eta_{\mathrm{L}}\right) / 2\right)\right)+\left(1-\mathrm{X}^{1}\right) \alpha\left(\mathrm{d}_{1}+\mathrm{c}_{1}\left(\left(\eta_{\mathrm{H}}+\eta_{\mathrm{L}}\right) / 2\right)\right) . \\
& \left.\mathrm{W}^{1}=\mathrm{d}_{1}+\mathrm{c}_{1}\left(\left(\eta_{\mathrm{L}}+\eta_{\mathrm{H}}\right) / 2\right)+\mathrm{X}^{1}(\alpha-\beta)\left[\mathrm{d}_{2}+\mathrm{c}_{2}\left(\left(\eta_{\mathrm{H}}+\eta_{\mathrm{L}}\right) / 2\right)\right]+\left(1-\mathrm{X}^{1}\right)(\alpha-\beta)\left[\mathrm{d}_{1}+\mathrm{c}_{1}\left(\eta_{\mathrm{H}}+\eta_{\mathrm{L}}\right) / 2\right)\right]
\end{aligned}
$$

Here the left hand side of the above equation (the top equation) gives the expected wages that the worker will be paid in his career. Denoting the wage paid in the first period as $\mathrm{W}^{1}$, the expected wages in period 2 consists of two components: (1) the wage paid if the worker is promoted to job 2 and (2) is the wage paid if the worker is not promoted. The respective probabilities are signified with $\left(\mathrm{X}^{1}\right)$ and $\left(1-\mathrm{X}^{1}\right)$ respectively. The right hand side gives the expected productivity of the worker in the two periods. As in the wages paid, this takes into account the respective productivities if the worker is promoted and also the case where he is not promoted. The equality of the wages paid over the two periods with the productivity of the workers over the same time span is an artifact of the net expected zero profit condition of the employer. 
Proof of Lemma 2: We present the proof only for the case that is most empirically relevant in our study, namely that $\mathrm{d}_{2}$ decreases by enough when $\mathrm{c}_{2}$ is increased so that $\mathrm{d} \eta^{\prime} / \mathrm{dc}_{2}>0$. Proofs for the other cases, in which $\mathrm{d}_{2}$ changes so that $\mathrm{d} \eta^{\prime} / \mathrm{dc}_{2}<0$ or $\mathrm{d}^{\prime} / \mathrm{dc}_{2}$ $=0$ are available upon request. From (3) we know that $\alpha\left(\mathrm{d}_{2}+\mathrm{c}_{2} \eta^{*}\right)-\beta\left[\mathrm{d}_{2}+\mathrm{c}_{2}\left(\eta^{*}+\eta_{\mathrm{H}}\right) / 2\right]=$ $\alpha\left(d_{1}+c_{1} \eta^{*}\right)-\beta\left[d_{1}+c_{1}\left(\eta^{*}+\eta_{L}\right) / 2\right]$. The Implicit Function Theorem implies

$\frac{\partial \eta^{*}}{\partial c_{2}}=-\frac{\eta^{*}}{\left(c_{2}-c_{1}\right)}-\frac{(\alpha-\beta)}{(\alpha-\beta / 2)} \cdot \frac{\partial d_{2}}{\partial c_{2}} \cdot \frac{1}{\left(c_{2}-c_{1}\right)}$.

From the fact that $\eta^{\prime}=\left(\mathrm{d}_{1}-\mathrm{d}_{2}\right) /\left(\mathrm{c}_{2}-\mathrm{c}_{1}\right)$, we get that $\frac{\partial d_{2}}{\partial c_{2}}=-\eta^{\prime}-\left(c_{2}-c_{1}\right) \frac{\partial \eta^{\prime}}{\partial c_{2}}$.

Substituting this in above we get

$\frac{\partial \eta^{*}}{\partial c_{2}}=-\frac{\eta^{*}}{\left(c_{2}-c_{1}\right)}-\frac{(\alpha-\beta)}{(\alpha-\beta / 2)} \cdot \frac{1}{\left(c_{2}-c_{1}\right)} \cdot\left(-\eta^{\prime}-\left(c_{2}-c_{1}\right) \frac{\partial \eta^{\prime}}{\partial c_{2}}\right)$

On simplification this becomes:

$\frac{\partial \eta^{*}}{\partial c_{2}}=\frac{1}{\left(c_{2}-c_{1}\right)}\left[\frac{(\alpha-\beta)}{(\alpha-\beta / 2)} \eta^{\prime}-\eta^{*}\right]+\frac{(\alpha-\beta)}{(\alpha-\beta / 2)} \cdot \frac{\partial \eta^{\prime}}{\partial c_{2}}$

We define $\frac{(\alpha-\beta)}{(\alpha-\beta / 2)}=\mathrm{Y}<1$. Hence the above expression can be written as: $(\alpha-\beta / 2)$

$\frac{\partial \eta^{*}}{\partial c_{2}}=\frac{1}{\left(c_{2}-c_{1}\right)}\left[Y \eta^{\prime}-\eta^{*}\right]+Y \cdot \frac{\partial \eta^{\prime}}{\partial c_{2}}$

Since $\eta^{\prime}<\eta^{*}$ and $0<\mathrm{Y}<1$, we know $\frac{1}{\left(c_{2}-c_{1}\right)}\left[Y \eta^{\prime}-\eta^{*}\right]<0$. And since $\frac{\partial \eta^{\prime}}{\partial c_{2}}>0,\left(\mathrm{~d} \eta^{\prime} / \mathrm{dc} c_{2}-\mathrm{d} \eta^{*} / \mathrm{dc} c_{2}\right)>0$

Proof of Proposition 2: From Lemma 2 we know that the cut-off ability workers who are promoted, $\eta^{*}$, varies with $c_{2}$. We get the cut-off $c_{2}\left(i . e c^{*}{ }_{2}\right)$ from equation 3 , which gives the marginal condition for the workers investing decision in the promotion contract case. Note that this is dependent on the costs of investment which is $\mathrm{z}$.

$\left[\mathrm{d}_{2}+\mathrm{c}_{2}\left(\left(\eta^{*}+\eta_{\mathrm{H}}\right) / 2\right)-\left\{\mathrm{d}_{1}+\mathrm{c}_{1}\left(\left(\eta^{*}+\eta_{\mathrm{L}}\right) / 2\right)\right\}\right]\left[\left\{\left(\eta_{\mathrm{H}^{-}} \eta^{*}\right) /\left(\eta_{\mathrm{H}^{-}} \eta_{\mathrm{L}}\right)\right\}-\left\{\left(\eta_{\mathrm{H}^{-}} \alpha \eta^{*}\right) /\left(\eta_{\mathrm{H}^{-}} \eta_{\mathrm{L}}\right)\right\}\right]=$ $\mathrm{Z}$

Because of the condition on $\alpha$ which ensures that workers are not fired, we know $\left\{\left(\eta_{\mathrm{H}^{-}} \alpha\right.\right.$ $\left.\left.\eta^{*}\right) /\left(\eta_{\mathrm{H}^{-}} \eta_{\mathrm{L}}\right)\right\}=0$. We can write the left hand side of the above equation with $\phi$ as: 
$\phi=\beta\left[d_{2}+c_{2}\left(\left(\eta^{*}+\eta_{\mathrm{H}}\right) / 2\right)-\mathrm{d}_{1}+\mathrm{c}_{1}\left(\left(\eta^{*}+\eta_{\mathrm{L}}\right) / 2\right)\right]\left[\left\{\left(\eta_{\mathrm{H}^{-}} \eta^{*}\right) /\left(\eta_{\mathrm{H}^{-}} \eta_{\mathrm{L}}\right)\right\}\right]$

Using equation ( $\left.2^{\prime}\right)$ we can simplify this further to:

$\phi=\alpha\left[\mathrm{d}_{2}+\mathrm{c}_{2} \eta^{*}-\left\{\mathrm{d}_{1}+\mathrm{c}_{1} \eta^{*}\right\}\right]\left[\left\{\left(\eta_{\mathrm{H}^{-}} \eta^{*}\right) /\left(\eta_{\mathrm{H}^{-}} \eta_{\mathrm{L}}\right)\right\}\right]$

or, $\phi=\alpha\left[d_{2}-d_{1}+\left(c_{2}-c_{1}\right) \eta^{*}\right]\left[\left\{\left(\eta_{H^{-}} \eta^{*}\right) /\left(\eta_{H^{-}} \eta_{L}\right)\right\}\right]$

Differentiating the above expression with respect to $c_{2}$ we get:

$\partial \phi / \partial c_{2}=\left[\left(c_{2}-c_{1}\right) \alpha \partial \eta^{*} / \partial c_{2}+\alpha \eta^{*}\right] \cdot X_{1}+\left[\left\{(-1) \cdot \partial \eta^{*} / \partial c_{2}\right\} / \eta_{H}-\eta_{L}\right] \cdot X_{2}$

where $X_{1}=\left[\left\{\left(\eta_{\mathrm{H}}-\eta^{*}\right) /\left(\eta_{\mathrm{H}}-\eta_{\mathrm{L}}\right)\right\}\right]$ and $\mathrm{X}_{2}=\alpha\left[\mathrm{d}_{2}-\mathrm{d}_{1}+\left(\mathrm{c}_{2}-\mathrm{c}_{1}\right) \eta^{*}\right]$

We know that $\partial \eta^{*} / \partial \mathrm{c}_{2}>0$

So the first term of $\partial \phi / \partial c_{2}$ is zero, and $X_{1}$ and $X_{2}$ are positive.

Thus $\partial \phi / \partial c_{2}>0$.

And since $\phi$ is a continuous function and $\phi\left(c_{2}^{\prime}\right)<z<\phi\left(c_{2}^{\prime \prime}\right)$, we know from the Intermediate Value Theorem (IVT) that there exists a $c^{*}{ }_{2}$ for which $(\phi()-.\mathrm{z})$ is equal to zero.

\section{Proof of Testable Implication 3:}

The wages of the marginal Invisible worker who is promoted as against the worker who is kept in job 1 is given by,

$\mathrm{W}_{\mathrm{I}}^{\mathrm{P}}=\beta\left[\mathrm{d}_{2}+\mathrm{c}_{2}\left(\eta^{*}+\eta_{\mathrm{H}}\right) / 2\right]$

$\mathrm{w}_{\mathrm{I}}^{\mathrm{NP}}=\beta\left[\mathrm{d}_{1}+\mathrm{c}_{1}\left(\eta^{*}+\eta_{\mathrm{L}}\right) / 2\right]$ respectively.

Hence, $\xi\left(c_{2}\right)=\mathrm{w}_{\mathrm{I}}{ }^{\mathrm{P}}-\mathrm{w}_{\mathrm{I}}{ }^{\mathrm{NP}}=\beta\left[\mathrm{d}_{2}+\mathrm{c}_{2}\left(\eta^{*}+\eta_{\mathrm{H}}\right) / 2\right]-\beta\left[\mathrm{d}_{1}+\mathrm{c}_{1}\left(\eta^{*}+\eta_{\mathrm{L}}\right) / 2\right]$

To show the above we should prove that, $\frac{\partial \xi\left(c_{2}\right)}{\partial\left(c_{2}\right)}<0$.

Since we know that $\left(d_{1}+c_{1} \eta^{\prime}\right)=\left(d_{2}+c_{2} \eta^{\prime}\right)$, by substituting for $d_{2}$ in the above equation we can simplify to,

$\xi\left(c_{2}\right)=\beta\left[d_{1}+\left(c_{1}-c_{2}\right) \eta^{\prime}+c_{2}\left(\eta^{*}+\eta_{H}\right) / 2-d_{1}-c_{1}\left(\eta^{*}+\eta_{L}\right) / 2\right]$.

By partially differentiating the above and then simplifying with respect to $c_{2}$ we get: $\frac{\partial \xi\left(c_{2}\right)}{\partial\left(c_{2}\right)}=\left[-\eta^{\prime}+\left(\eta_{H} / 2\right)\right]$.

By substituting for $\eta^{\prime}$ we can further simplify the above to get $\frac{\partial \xi\left(c_{2}\right)}{\partial\left(c_{2}\right)}=\left(c_{2}-c_{1}+2 \Delta\right)^{26}$, which we know from assumption (1), as negative. Hence $\frac{\partial \xi\left(c_{2}\right)}{\partial\left(c_{2}\right)}<0$.

${ }^{26}$ Where $\Delta=\left(\mathrm{d}_{1}-\mathrm{d}_{2}\right) / \eta_{\mathrm{H}}$. 


\section{APPENDIX B}

Occupation codes for the workers in the dataset were derived primarily using information on job titles. First, the job titles in the personnel records were compared to the (searchable) Census 2000 alphabetical list of occupations (http://www.census.gov/hhes/www/ioindex/occ_a.html). We searched for the closest possible title. When there was no comparable title listed in the occupation codes, we looked on www.google.com for the job title to determine what the job might entail and then looked for an appropriate occupation code accordingly.

Frequently, the job title included an acronym, such as "QA technician" or "AP clerk" - in such cases, we searched for possible acronyms from www.acronymfinder.com, and used our best estimate of which one fit our data. In many cases, there were multiple possible occupation codes that could fit the job title. In these instances, we made use of the secondary job title variable, function/skill, to determine what broad occupation category the worker belonged in-such as finance, manufacturing, engineering, etc. and then narrowed down the occupation codes accordingly.

Additionally, as a last resort, the wage information was used-in the sense that we expected that a high wage or an annually-paid salary indicated a more white collar job, a monthly-paid salary indicated a technical or clerical job, and a low-paying or hourly-paid wage indicated a manufacturing job. Some job titles could not be coded. The majority of these were internships, trainees, co-ops, temps and contractors.

Since the NCS data are coded according to the 1990 Census occupation codes, it was necessary to convert to those categories. We used a table showing the redistribution of the 1990 Census occupation into the new 2000 categories, we then assigned a 1990 occupation code, using the code with the highest conversion percentage. For example, although three 1990 occupation codes convert into the 2000 occupation code 570 (secretaries and administrative assistants), including 303 (general office supervisors), 313 (secretaries), and 336 (records clerks), the majority of them converted to 313 , so we would use that code to categorize all secretary jobs.

In practice, job hierarchies exist both within and across occupations. An example of a within-occupation job hierarchy is assistant professor $\rightarrow$ associate professor $\rightarrow$ full professor, whereas an example of a hierarchy defined across occupations might be computer programmer $\rightarrow$ general manager. Thus, promotions sometimes involve changes in occupation, though most frequently promotions do not involve a change in occupation (especially within the same establishment). In our data, using two-digit (three-digit) occupation codes, only 6.7 (7.9) percent of promotions involve a change in occupation. We note that although only a small fraction of promotions cross occupations, these naturally entail greater task variability across hierarchical levels than do withinoccupation promotions. Using two-digit occupations, the following table displays the 1148 transitions involving positive level changes (i.e. promotions). 


\section{Table B1 Two-Digit Occupational Transitions Resulting from Promotions \\ Number Occupation Before Occupation After}

\begin{tabular}{|c|c|c|}
\hline 105 & Executive & Executive \\
\hline 2 & Mgmt related & Executive \\
\hline 1 & Math/Computer Science & Executive \\
\hline 1 & Records & Executive \\
\hline 1 & Mechanic & Executive \\
\hline 53 & Mgmt related & Mgmt related \\
\hline 42 & Engineers & Engineers \\
\hline 1 & Other precision worker & Engineers \\
\hline 23 & Math/Computer Science & Math/Computer Science \\
\hline 19 & Natural sciences & Natural sciences \\
\hline 10 & Other Professional & Other Professional \\
\hline 1 & Health Technician & Other Professional \\
\hline 1 & Health Technician & Health Technician \\
\hline 38 & Engineering Technician & Engineering Technician \\
\hline 20 & Other Technician & Other Technician \\
\hline 3 & Sales Mgr & Sales Mgr \\
\hline 1 & Sales-Finance/Business & Sales-Finance/Business \\
\hline 1 & Exec & Sales Rep \\
\hline 108 & Sales Rep & Sales Rep \\
\hline 1 & Records & Sales Rep \\
\hline 1 & Other Sales & Other Sales \\
\hline 2 & Exec & Administrative Supervisor \\
\hline 9 & Administrative Supervisor & Administrative Supervisor \\
\hline 1 & Secretary & Administrative Supervisor \\
\hline 2 & Mechanic & Administrative Supervisor \\
\hline 8 & Computer Operator & Computer Operator \\
\hline 1 & Mechanic & Computer Operator \\
\hline 15 & Secretary & Secretary \\
\hline 51 & Records & Records \\
\hline 4 & Other Administrative & Records \\
\hline 1 & MachineOp & Records \\
\hline 1 & Assembler & Records \\
\hline 1 & Records & Other Administrative \\
\hline 142 & Other Administrative & Other Administrative \\
\hline 1 & Machine Operator & Other Administrative \\
\hline 2 & Handlers & Other Administrative \\
\hline 2 & Other Laborer & Other Administrative \\
\hline 1 & Protective Service & Protective Service \\
\hline 2 & Building Service & Building Service \\
\hline 142 & Mechanic & Mechanic \\
\hline 3 & Other Administrative & Other precision worker \\
\hline 128 & OtherPrec & Other precision worker \\
\hline 4 & Assembler & Other precision worker \\
\hline 2 & Handlers & Other precision worker \\
\hline 4 & Other precision worker & Machine Operator \\
\hline 58 & Machine Operator & Machine Operator \\
\hline 8 & Assembler & Machine Operator \\
\hline
\end{tabular}


Handlers

Building Service

Other precision worker

Machine Operator

Assembler

Handlers

Other Laborer

Vehicle Operator

Other Administrative

Other Transportation

Mgmt related

Secretary

Other Administrative

Building Service

Other precision worker

Machine Operator

Assembler

Handlers

Assembler

Other Laborer
Machine Operator

Assembler

Assembler

Assembler

Assembler

Assembler

Assembler

Vehicle Operator

Other Transportation

Other Transportation

Handlers

Handlers

Handlers

Handlers

Handlers

Handlers

Handlers

Handlers

Other Laborer

Other Laborer

Total: 1148 (93.3\% of promotions are within-occupation) 
Table 1: Previous Literature on Racial Differences in Promotions

\begin{tabular}{|c|c|c|c|c|}
\hline Paper & Occupation & Data Set & Promotion Rates & $\begin{array}{c}\text { Wage } \\
\text { Changes }\end{array}$ \\
\hline $\begin{array}{l}\text { Anandarajan } \\
\text { (2002) }\end{array}$ & Auditors & $\begin{array}{l}\text { Questionnaire; } \\
644 \\
\text { observations }\end{array}$ & $\begin{array}{l}\text { No difference in } \\
\text { promotion (to manager) } \\
\text { rates of whites and non- } \\
\text { whites }\end{array}$ & N.A. \\
\hline $\begin{array}{l}\text { Baldwin } \\
\text { (1996) }\end{array}$ & $\begin{array}{l}\text { U.S. Army } \\
\text { Officers }\end{array}$ & $\begin{array}{l}\text { Request made } \\
\text { to Army; 1980- } \\
\text { 1993; 123,000 } \\
\text { observations }\end{array}$ & $\begin{array}{l}\text { Blacks, Hispanics, } \\
\text { Asian/Pacific Islanders, } \\
\text { and Native Americans } \\
\text { had lower promotion } \\
\text { rates than non-Hispanic } \\
\text { whites to ranks of } \\
\text { Captain, Major, and Lt. } \\
\text { Colonel, but for Colonel } \\
\text { Hispanics had lower and } \\
\text { Asian/Pacific Islander } \\
\text { higher rates }\end{array}$ & N.A. \\
\hline $\begin{array}{l}\text { Bellemore } \\
(2001)\end{array}$ & $\begin{array}{l}\text { Professional } \\
\text { Baseball }\end{array}$ & $\begin{array}{l}\text { Author's } \\
\text { creation; 1968- } \\
9,1976-7, \\
\text { 1991-7; } 1,743 \\
\text { observations }\end{array}$ & $\begin{array}{l}\text { Promotion rates to major } \\
\text { league are } 5.2 \% \text { less } \\
\text { likely for blacks, } 5.4 \% \\
\text { less likely for Hispanics }\end{array}$ & N.A. \\
\hline $\begin{array}{l}\text { Killingsworth } \\
\text { and Reimers } \\
\text { (1983) }\end{array}$ & $\begin{array}{l}\text { Civilian } \\
\text { Employees, US } \\
\text { Army Base }\end{array}$ & $\begin{array}{l}\text { DoD Civilian } \\
\text { Personnel } \\
\text { Information } \\
\text { System; 1975- } \\
8 ; 16,045 \\
\text { observations }\end{array}$ & $\begin{array}{l}\text { Non-whites less likely to } \\
\text { be promoted }\end{array}$ & $\begin{array}{l}\text { Non-whites } \\
\text { receive less } \\
\text { compensation } \\
\text { after } \\
\text { promotion }\end{array}$ \\
\hline Landau (1995) & $\begin{array}{l}\text { Managerial and } \\
\text { professional } \\
\text { employees at a } \\
\text { Fortune } 500 \\
\text { company }\end{array}$ & $\begin{array}{l}\text { Questionnaire; } \\
\text { no years given; } \\
1268 \\
\text { observations }\end{array}$ & $\begin{array}{l}\text { Managers rated } \\
\text { "promotion potential" } \\
\text { lower for blacks and } \\
\text { Asians, but not Hispanics }\end{array}$ & N.A. \\
\hline $\begin{array}{l}\text { Mellor and } \\
\text { Paulin (1995) }\end{array}$ & $\begin{array}{l}\text { Employees in } \\
\text { two branches } \\
\text { of a financial } \\
\text { services firm }\end{array}$ & $\begin{array}{l}\text { Company data; } \\
1988-90 ; \\
\text { approx. } 1025 \\
\text { observations }\end{array}$ & N.A. & $\begin{array}{l}\text { Return to } \\
\text { promotions is } \\
\text { not higher for } \\
\text { whites than } \\
\text { non-whites }\end{array}$ \\
\hline $\begin{array}{l}\text { Paulin and } \\
\text { Mellor (1996) }\end{array}$ & $\begin{array}{l}\text { Employees at } \\
\text { the home office } \\
\text { of a medium- } \\
\text { sized financial } \\
\text { firm }\end{array}$ & $\begin{array}{l}\text { Company data; } \\
1988-90 ; 575 \\
\text { observations }\end{array}$ & $\begin{array}{l}\text { Promotion rate for non- } \\
\text { white males is } 17 \% \\
\text { below white males, but } \\
\text { no difference for non- } \\
\text { white females relative to } \\
\text { white males; also, } \\
\text { gender/race composition } \\
\text { of occupations sometimes } \\
\text { affects promotion rates }\end{array}$ & N.A. \\
\hline $\begin{array}{l}\text { Pergamit and } \\
\text { Veum (1999) }\end{array}$ & $\begin{array}{l}\text { Private-sector } \\
\text { workers not }\end{array}$ & $\begin{array}{l}\text { National } \\
\text { Longitudinal }\end{array}$ & $\begin{array}{l}\text { Black men } 1.7 \% \text { less } \\
\text { likely to be promoted }\end{array}$ & N.A. \\
\hline
\end{tabular}




\begin{tabular}{|c|c|c|c|c|}
\hline & $\begin{array}{l}\text { self-employed } \\
\text { and working } \\
>=30 \text { hours per } \\
\text { week; all } 25-33 \\
\text { years old in } \\
1990\end{array}$ & $\begin{array}{l}\text { Survey of } \\
\text { Youth; 1990; } \\
\text { approx. 3,355 } \\
\text { observations }\end{array}$ & $\begin{array}{l}\text { than white men, Hispanic } \\
\text { men } 10.1 \% \text { less likely }\end{array}$ & \\
\hline $\begin{array}{l}\text { Powell and } \\
\text { Butterfield } \\
\text { (1997) }\end{array}$ & $\begin{array}{l}\text { Management in } \\
\text { a cabinet-level } \\
\text { federal } \\
\text { department }\end{array}$ & $\begin{array}{l}\text { Promotion } \\
\text { files; 1987- } \\
\text { 1994; 300 } \\
\text { observations }\end{array}$ & $\begin{array}{l}\text { There were not racial } \\
\text { differences in promotion } \\
\text { rates; however, non- } \\
\text { whites were less likely to } \\
\text { be already employed in } \\
\text { the department studied } \\
\text { and on average had more } \\
\text { job experience, both of } \\
\text { which decreased a } \\
\text { candidate's chances of } \\
\text { receiving promotion }\end{array}$ & N.A. \\
\hline $\begin{array}{l}\text { Pudney and } \\
\text { Shields } \\
\text { (2000a) }\end{array}$ & $\begin{array}{l}\text { Nurses in the } \\
\text { UK's National } \\
\text { Health Service }\end{array}$ & $\begin{array}{l}\text { Survey } \\
\text { conducted by } \\
\text { Department of } \\
\text { Health; 1994; } \\
8,919 \\
\text { observations }\end{array}$ & $\begin{array}{l}\text { Non-whites had } \\
\text { significant disadvantage } \\
\text { in speed of promotion }\end{array}$ & N.A. \\
\hline $\begin{array}{l}\text { Pudney and } \\
\text { Shields } \\
\text { (2000b) }\end{array}$ & $\begin{array}{l}\text { Nurses in the } \\
\text { UK's National } \\
\text { Health Service }\end{array}$ & $\begin{array}{l}\text { Survey } \\
\text { conducted by } \\
\text { Department of } \\
\text { Health; 1994; } \\
8,919 \\
\text { observations }\end{array}$ & $\begin{array}{l}\text { Non-whites had } \\
\text { significant disadvantage } \\
\text { in speed of promotion }\end{array}$ & N.A. \\
\hline $\begin{array}{l}\text { Stewart and } \\
\text { Firestone } \\
\text { (1992) }\end{array}$ & $\begin{array}{l}\text { U.S. Military } \\
\text { Officers }\end{array}$ & $\begin{array}{l}\text { DoD } \\
\text { tabulation; } \\
\text { 1979-88; }\end{array}$ & $\begin{array}{l}\text { It is difficult to predict } \\
\text { promotion rates for } \\
\text { various specifications of } \\
\text { the model.; thus it cannot } \\
\text { be concluded that there } \\
\text { are racial differences in } \\
\text { promotion. }\end{array}$ & N.A. \\
\hline $\begin{array}{l}\text { Sundstrom } \\
\text { (1990) }\end{array}$ & $\begin{array}{l}\text { Railroadmen in } \\
\text { the American } \\
\text { South }\end{array}$ & $\begin{array}{l}\text { U.S. Census; } \\
1910\end{array}$ & $\begin{array}{l}\text { Blacks were not } \\
\text { promoted beyond mid- } \\
\text { level positions; difference } \\
\text { in promotability helped } \\
\text { create wage disparities } \\
\text { between whites and } \\
\text { blacks in same positions. }\end{array}$ & N.A. \\
\hline
\end{tabular}




\begin{tabular}{|l|c|c|}
\hline Table 2a: Descriptive Statistics & \multicolumn{2}{l|}{} \\
\hline & Mean & No. Obs. \\
\hline Promotion & 0.010 & 121760 \\
\hline Nonwhite & 0.305 & 121760 \\
\hline Female & 0.512 & 121760 \\
\hline Age & 31.11 & 121760 \\
\hline Tenure (months) & 13.85 & 121760 \\
\hline Level tenure (months) & 11.03 & 121760 \\
\hline Married & 0.508 & 121760 \\
\hline Part-time & 0.098 & 121579 \\
\hline < BA & 0.212 & 47956 \\
\hline BA & 0.616 & 47956 \\
\hline$>$ BA & 0.173 & 47956 \\
\hline Performance 1 & 0.129 & 56164 \\
\hline Performance 2 & 0.639 & 56164 \\
\hline Performance 3 & 0.224 & 56164 \\
\hline Performance 4 & 0.008 & 56164 \\
\hline Coefficient of skill variation (3 digit) & 0.364 & 113058 \\
\hline Coefficient of skill variation (2 digit) & 0.405 & 113122 \\
\hline
\end{tabular}




\begin{tabular}{|l|c|}
\hline \multicolumn{2}{|l|}{ Table 2b: Promotion Probabilities by Worker Characteristics } \\
\hline & Probability of Promotion \\
\hline Nonwhite & 0.009 \\
\hline White & 0.010 \\
\hline Female & 0.010 \\
\hline Male & 0.010 \\
\hline Age<25 & 0.010 \\
\hline Age 25-34 & 0.011 \\
\hline Age 35-44 & 0.009 \\
\hline Age 45-54 & 0.005 \\
\hline Age 55+ & 0.003 \\
\hline Tenure <1 year & 0.008 \\
\hline Tenure 1 year - <2 year & 0.012 \\
\hline Tenure >2 years & 0.011 \\
\hline Level tenure $<1$ year & 0.009 \\
\hline Level tenure 1 year $-<2$ year & 0.013 \\
\hline Level tenure $>2$ years & 0.009 \\
\hline Married & 0.009 \\
\hline Unmarried & 0.010 \\
\hline Part-time & 0.008 \\
\hline Full-time & 0.010 \\
\hline$<$ BA & 0.007 \\
\hline BA & 0.013 \\
\hline$>$ BA & 0.012 \\
\hline Performance 1 & 0.003 \\
\hline Performance 2 & 0.009 \\
\hline Performance 3 & 0.014 \\
\hline Performance 4 & 0.021 \\
\hline Manager & 0.015 \\
\hline Professional & 0.010 \\
\hline Technical & 0.010 \\
\hline Sales & 0.011 \\
\hline Clerical & 0.008 \\
\hline Service & 0.004 \\
\hline Precision Crafts & 0.025 \\
\hline Machine operator/assembler & 0.005 \\
\hline Handler/other laborer & 0.010 \\
\hline
\end{tabular}




\begin{tabular}{|c|c|c|c|c|c|}
\hline & Model I & Model II & Model III & Model IV & Model V \\
\hline Nonwhite & $\begin{array}{l}-0.075^{* * * *} \\
(0.0242)\end{array}$ & $\begin{array}{l}-0.074^{* * * *} \\
(0.024)\end{array}$ & $\begin{array}{l}-0.064^{*} \\
(0.042)\end{array}$ & $\begin{array}{l}-0.059 * \\
(0.039)\end{array}$ & $\begin{array}{l}-0.091^{*} \\
(0.055) \\
\end{array}$ \\
\hline Female & & $\begin{array}{l}0.019 \\
(0.022)\end{array}$ & $\begin{array}{l}0.030 \\
(0.034)\end{array}$ & $\begin{array}{l}-0.015 \\
(0.033)\end{array}$ & $\begin{array}{l}-0.013 \\
(0.044)\end{array}$ \\
\hline Age & & $\begin{array}{l}0.033^{\text {***** }} \\
(0.009)\end{array}$ & $\begin{array}{l}-0.011 \\
(0.017)\end{array}$ & $\begin{array}{l}0.022 \\
(0.016)\end{array}$ & $\begin{array}{l}0.012 \\
(0.026)\end{array}$ \\
\hline $\mathrm{Age}^{2} / 10$ & & $\begin{array}{l}-0.006^{* * * *} \\
(0.001)\end{array}$ & $\begin{array}{l}-0.001 \\
(0.002)\end{array}$ & $\begin{array}{l}-0.005^{* *} \\
(0.002)\end{array}$ & $\begin{array}{l}-0.004 \\
(0.004)\end{array}$ \\
\hline Tenure & & $\begin{array}{l}0.0162^{* * *} \\
(0.006)\end{array}$ & $\begin{array}{l}0.016^{* *} \\
(0.008)\end{array}$ & $\begin{array}{l}-0.013 \\
(0.010) \\
\end{array}$ & $\begin{array}{l}-0.015 \\
(0.013) \\
\end{array}$ \\
\hline Tenure $^{2} / 10$ & & $\begin{array}{l}-0.003^{* * *} \\
(0.000)\end{array}$ & $\begin{array}{l}-0.003^{* * *} \\
(0.002)\end{array}$ & $\begin{array}{l}0.002 \\
(0.002)\end{array}$ & $\begin{array}{l}0.002 \\
(0.002)\end{array}$ \\
\hline Level tenure & & $\begin{array}{l}0.018^{* * * *} \\
(0.006)\end{array}$ & $\begin{array}{l}0.048^{* * * *} \\
(0.009)\end{array}$ & $\begin{array}{l}0.063^{* * * *} \\
(0.011)\end{array}$ & $\begin{array}{l}0.099^{* * * *} \\
(0.014)\end{array}$ \\
\hline Level tenure $^{2} / 10$ & & $\begin{array}{l}-0.006^{* * * *} \\
(0.002)\end{array}$ & $\begin{array}{l}-0.011^{* * * *} \\
(0.002)\end{array}$ & $\begin{array}{l}-0.013^{* * * *} \\
(0.002)\end{array}$ & $\begin{array}{l}-0.020^{* * * *} \\
(0.003)\end{array}$ \\
\hline Married & & $\begin{array}{l}-0.024 \\
(0.023)\end{array}$ & $\begin{array}{l}0.011 \\
(0.036)\end{array}$ & $\begin{array}{l}-0.054 \\
(0.034)\end{array}$ & $\begin{array}{l}-0.045 \\
(0.045)\end{array}$ \\
\hline Part-time & & $\begin{array}{l}-0.015 \\
(0.039)\end{array}$ & $\begin{array}{l}-0.437^{* * * *} \\
(0.139)\end{array}$ & $\begin{array}{l}-0.105 \\
(0.106)\end{array}$ & $\begin{array}{l}-0.413^{*} \\
(0.250)\end{array}$ \\
\hline$<\mathrm{BA}$ & & & $\begin{array}{l}-0.177^{* * * *} \\
(0.059)\end{array}$ & & $\begin{array}{l}-0.307^{* * * *} \\
(0.082)\end{array}$ \\
\hline $\mathrm{BA}$ & & & $\begin{array}{l}-0.034 \\
(0.045)\end{array}$ & & $\begin{array}{l}-0.055 \\
(0.055)\end{array}$ \\
\hline Performance 1 & & & & $\begin{array}{l}-0.689^{* * * *} \\
(0.156)\end{array}$ & $\begin{array}{l}-0.554^{* * *} \\
(0.253)\end{array}$ \\
\hline Performance 2 & & & & $\begin{array}{l}-0.366^{* * * * *} \\
(0.142)\end{array}$ & $\begin{array}{l}-0.218 \\
(0.238)\end{array}$ \\
\hline Performance 3 & & & & $\begin{array}{l}-0.174 \\
(0.144)\end{array}$ & $\begin{array}{l}0.031 \\
(0.240)\end{array}$ \\
\hline Constant & $\begin{array}{l}-2.312^{* * *} \\
(0.013)\end{array}$ & 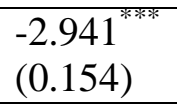 & $\begin{array}{l}-2.285^{* * * *} \\
(0.296)\end{array}$ & $\begin{array}{l}-2.533^{* * * *} \\
(0.308)\end{array}$ & $\begin{array}{l}-2.597^{* * * *} \\
(0.531)\end{array}$ \\
\hline No. obs. & 121,759 & 121,578 & 47,913 & 56,217 & 30,929 \\
\hline Pseudo- $\mathrm{R}^{2}$ & 0.001 & 0.013 & 0.038 & 0.035 & 0.068 \\
\hline
\end{tabular}




\begin{tabular}{|c|c|c|c|c|}
\hline . & Model I & Model II & Model III & Model IV \\
\hline Nonwhite & $\begin{array}{l}-0.340^{* * *} \\
(0.155) \\
\end{array}$ & $\begin{array}{l}-0.348^{* * *} \\
(0.161)\end{array}$ & $\begin{array}{l}-0.248^{* * *} \\
(0.118)\end{array}$ & $\begin{array}{l}-0.250^{* *} \\
(0.119)\end{array}$ \\
\hline $\begin{array}{l}\text { Coefficient of Variation (3-digit } \\
\text { occupations) }\end{array}$ & $\begin{array}{l}-1.720^{* * * *} \\
(0.201)\end{array}$ & $\begin{array}{l}-1.968^{* * * *} \\
(0.220)\end{array}$ & $\begin{array}{l}-3.529^{* * * *} \\
(0.400)\end{array}$ & $\begin{array}{l}-4.087^{* * *} \\
(0.426)\end{array}$ \\
\hline $\begin{array}{l}\text { (Coefficient of Variation) }^{2} \text { (3- } \\
\text { digit occupations) }\end{array}$ & & & $\begin{array}{l}2.518^{* * * *} \\
(0.436)\end{array}$ & $\begin{array}{l}2.945^{* * *} \\
(0.452)\end{array}$ \\
\hline CV $(3$ digit $) \times$ Nonwhite & $\begin{array}{l}0.757^{* *} \\
(0.433)\end{array}$ & $\begin{array}{l}0.776^{* *} \\
(0.452)\end{array}$ & $\begin{array}{l}0.507^{*} \\
(0.324)\end{array}$ & $\begin{array}{l}0.510^{*} \\
(0.326)\end{array}$ \\
\hline Female & & $\begin{array}{l}0.090^{* * * *} \\
(0.027)\end{array}$ & & $\begin{array}{l}0.090^{* * * *} \\
(0.027)\end{array}$ \\
\hline Age & & $\begin{array}{l}0.015 \\
(0.011)\end{array}$ & & $\begin{array}{l}0.014 \\
(0.011)\end{array}$ \\
\hline $\mathrm{Age}^{2}$ & & $\begin{array}{l}-0.000^{* * *} \\
(0.000)\end{array}$ & & $\begin{array}{l}-0.000^{* *} \\
(0.000)\end{array}$ \\
\hline Tenure & & $\begin{array}{l}0.015^{* *} \\
(0.007)\end{array}$ & & $\begin{array}{l}0.015^{* *} \\
(0.007)\end{array}$ \\
\hline Tenure $^{2}$ & & $\begin{array}{l}-0.000^{* *} \\
(0.000)\end{array}$ & & $\begin{array}{l}-0.000^{* *} \\
(0.000)\end{array}$ \\
\hline Level tenure & & $\begin{array}{l}0.019^{* * *} \\
(0.008)\end{array}$ & & $\begin{array}{l}0.020^{* * *} \\
(0.007)\end{array}$ \\
\hline$(\text { Level tenure })^{2}$ & & $\begin{array}{l}-0.000^{* * *} \\
(0.000)\end{array}$ & & $\begin{array}{l}-0.000^{* * *} \\
(0.000)\end{array}$ \\
\hline Married & & $\begin{array}{l}-0.052^{*} \\
(0.028)\end{array}$ & & $\begin{array}{l}-0.056^{* * *} \\
(0.028)\end{array}$ \\
\hline Part time & & 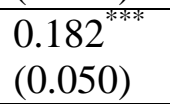 & & $\begin{array}{l}0.178^{* * *} \\
(0.050)\end{array}$ \\
\hline Constant & $\begin{array}{l}-1.705^{* * * *} \\
(0.068) \\
\end{array}$ & $\begin{array}{l}-1.954^{* * * *} \\
(0.206) \\
\end{array}$ & $\begin{array}{l}-1.402^{* * * *} \\
(0.089) \\
\end{array}$ & $\begin{array}{l}-1.586^{* * * *} \\
(0.217) \\
\end{array}$ \\
\hline No. obs. & 82,230 & 82,106 & 82,230 & 82,106 \\
\hline Pseudo- $\mathrm{R}^{2}$ & 0.013 & 0.028 & 0.015 & 0.030 \\
\hline
\end{tabular}




\begin{tabular}{|c|c|c|c|c|c|}
\hline \multicolumn{6}{|c|}{$\begin{array}{l}\text { TABLE 5: OLS Wage Growth Regressions for } \\
\text { Dependent Variable }=\ln \left(\text { wage }_{i t}\right)-\ln \left(\text { wage }_{i, t-1}\right)\end{array}$} \\
\hline & Model I & Model II & Model III & Model IV & Model V \\
\hline Promotion & $\begin{array}{l}0.088^{* * * *} \\
(0.006)\end{array}$ & $\begin{array}{l}0.088^{* * * * *} \\
(0.006)\end{array}$ & $\begin{array}{l}0.083^{* * * *} \\
(0.010)\end{array}$ & $\begin{array}{l}0.078^{* * * *} \\
(0.009)\end{array}$ & $\begin{array}{l}0.079^{* * * *} \\
(0.012)\end{array}$ \\
\hline Nonwhite & $\begin{array}{l}0.001^{* * * * *} \\
(0.000)\end{array}$ & $\begin{array}{l}0.001^{* * * * *} \\
(0.000)\end{array}$ & $\begin{array}{l}-0.001^{* * * * *} \\
(0.000)\end{array}$ & $\begin{array}{l}0.001^{* * * * * 1} \\
(0.000)\end{array}$ & $\begin{array}{l}0.000 \\
(0.000)\end{array}$ \\
\hline Promotion $x$ & $\begin{array}{l}0.006 \\
(0.009)\end{array}$ & $\begin{array}{l}0.006 \\
(0.009)\end{array}$ & $\begin{array}{l}0.006 \\
(0.019)\end{array}$ & $\begin{array}{l}0.014 \\
(0.015)\end{array}$ & $\begin{array}{l}0.010 \\
(0.026)\end{array}$ \\
\hline \multicolumn{6}{|l|}{ Nonwhite } \\
\hline Female & & $\begin{array}{l}-0.001^{* * * *} \\
(0.000)\end{array}$ & $\begin{array}{l}-0.001^{* * *} \\
(0.000)\end{array}$ & $\begin{array}{l}-0.001^{* *} \\
(0.000)\end{array}$ & $\begin{array}{l}-0.000 \\
(0.000)\end{array}$ \\
\hline Age & & $\begin{array}{l}-0.000 \\
(0.000)\end{array}$ & $\begin{array}{l}0.000^{*} \\
(0.000)\end{array}$ & $\begin{array}{l}-0.000^{* * *} \\
(0.000)\end{array}$ & $\begin{array}{l}-0.000^{*} \\
(0.000)\end{array}$ \\
\hline $\operatorname{Age}^{2} / 10$ & & $\begin{array}{l}0.000 \\
(0.000)\end{array}$ & $\begin{array}{l}-0.000^{*} \\
(0.000)\end{array}$ & $\begin{array}{l}0.000^{* * * *} \\
(0.000)\end{array}$ & $\begin{array}{l}0.000 \\
(0.000)\end{array}$ \\
\hline Tenure & & $\begin{array}{l}-0.000 \\
(0.000)\end{array}$ & $\begin{array}{l}-0.000^{*} \\
(0.000)\end{array}$ & $\begin{array}{l}0.000 \\
(0.000)\end{array}$ & $\begin{array}{l}0.000 \\
(0.000)\end{array}$ \\
\hline Tenure $^{2} / 10$ & & $\begin{array}{l}-0.000 \\
(0.000)\end{array}$ & $\begin{array}{l}0.000 \\
(0.000)\end{array}$ & $\begin{array}{l}-0.000 \\
(0.000)\end{array}$ & $\begin{array}{l}-0.000 \\
(0.000)\end{array}$ \\
\hline Level tenure & & $\begin{array}{l}-0.000^{* * * *} \\
(0.000)\end{array}$ & $\begin{array}{l}-0.001^{* * * *} \\
(0.000)\end{array}$ & $\begin{array}{l}-0.001^{* * * *} \\
(0.000)\end{array}$ & $\begin{array}{l}-0.001^{* * * * *} \\
(0.000)\end{array}$ \\
\hline Level tenure ${ }^{2} / 10$ & & $\begin{array}{l}0.000^{\text {****** }} \\
(0.000)\end{array}$ & $\begin{array}{l}0.000^{\text {***** }} \\
(0.000)\end{array}$ & $\begin{array}{l}0.000^{* * * * * *} \\
(0.000)\end{array}$ & $\begin{array}{l}0.000^{\text {***** }} \\
(0.000)\end{array}$ \\
\hline Married & & $\begin{array}{l}0.001^{\text {** }} \\
(0.000)\end{array}$ & $\begin{array}{l}0.000 \\
(0.000)\end{array}$ & $\begin{array}{l}-0.000 \\
(0.000)\end{array}$ & $\begin{array}{l}0.000 \\
(0.000)\end{array}$ \\
\hline Part-time & & $\begin{array}{l}-0.002^{* * * *} \\
(0.000)\end{array}$ & $\begin{array}{l}-0.001 \\
(0.001)\end{array}$ & $\begin{array}{l}0.001 \\
(0.001)\end{array}$ & $\begin{array}{l}-0.001 \\
(0.004)\end{array}$ \\
\hline$<\mathrm{BA}$ & & & $\begin{array}{l}-0.001 \\
(0.001)\end{array}$ & & $\begin{array}{l}-0.000 \\
(0.001)\end{array}$ \\
\hline $\mathrm{BA}$ & & & $\begin{array}{l}-0.001 \\
(0.001)\end{array}$ & & $\begin{array}{l}-0.000 \\
(0.000)\end{array}$ \\
\hline Performance 1 & & & & $\begin{array}{l}-0.003^{* *} \\
(0.001)\end{array}$ & $\begin{array}{l}-0.001 \\
(0.001)\end{array}$ \\
\hline Performance 2 & & & & $\begin{array}{l}-0.001 \\
(0.001)\end{array}$ & $\begin{array}{l}-0.000 \\
(0.001)\end{array}$ \\
\hline Performance 3 & & & & $\begin{array}{l}-0.000 \\
(0.001)\end{array}$ & $\begin{array}{l}0.001 \\
(0.001)\end{array}$ \\
\hline
\end{tabular}




\begin{tabular}{|c|c|c|c|c|c|}
\hline Constant & $\begin{array}{l}0.005^{* * *} \\
(0.000)\end{array}$ & $\begin{array}{l}0.012^{\text {**** }} \\
(0.001)\end{array}$ & $\begin{array}{l}0.008^{* * *} \\
(0.002)\end{array}$ & $\begin{array}{l}0.018^{* * * *} \\
(0.002) \\
\end{array}$ & $\begin{array}{l}0.015^{* * *} \\
(0.003)\end{array}$ \\
\hline No. obs. & 112,924 & 112,924 & 45,156 & 53,988 & 29,738 \\
\hline
\end{tabular}




\begin{tabular}{|c|c|c|c|c|}
\hline & Model I & Model II & Model III & Model IV \\
\hline Promotion & $\begin{array}{l}0.138^{* * * *} \\
(0.021)\end{array}$ & $\begin{array}{l}-0.137^{* * * *} \\
(0.021)\end{array}$ & $\begin{array}{l}0.139^{* * * *} \\
(0.021)\end{array}$ & $\begin{array}{l}0.138^{* * * *} \\
(0.021)\end{array}$ \\
\hline Nonwhite & $\begin{array}{l}0.000 \\
(0.001)\end{array}$ & $\begin{array}{l}0.000 \\
(0.001)\end{array}$ & $\begin{array}{l}-0.000 \\
(0.001)\end{array}$ & $\begin{array}{l}-0.000 \\
(0.001)\end{array}$ \\
\hline Promotion $\times$ Nonwhite & $\begin{array}{l}-0.032 \\
(0.033)\end{array}$ & $\begin{array}{l}-0.031 \\
(0.033)\end{array}$ & $\begin{array}{l}-0.032 \\
(0.033)\end{array}$ & $\begin{array}{l}-0.031 \\
(0.033)\end{array}$ \\
\hline $\begin{array}{l}\text { Coefficient of Variation (3-digit } \\
\text { occupations) }\end{array}$ & $\begin{array}{l}-0.002 \\
(0.002)\end{array}$ & $\begin{array}{l}-0.002 \\
(0.002)\end{array}$ & $\begin{array}{l}0.016^{* * * *} \\
(0.005)\end{array}$ & $\begin{array}{l}0.017^{* * * *} \\
(0.005)\end{array}$ \\
\hline $\begin{array}{l}\text { Promotion } \times \text { Coefficient of } \\
\text { Variation (3-digit occupations) }\end{array}$ & $\begin{array}{l}-0.143^{* *} \\
(0.058)\end{array}$ & $\begin{array}{l}-0.139^{* *} \\
(0.057)\end{array}$ & $\begin{array}{l}-0.147^{* * *} \\
(0.058)\end{array}$ & $\begin{array}{l}-0.142^{* * *} \\
(0.058)\end{array}$ \\
\hline CV $(3$ digit $) \times$ Nonwhite & $\begin{array}{l}0.001 \\
(0.002)\end{array}$ & $\begin{array}{l}0.001 \\
(0.002)\end{array}$ & $\begin{array}{l}0.002 \\
(0.002)\end{array}$ & $\begin{array}{l}0.002 \\
(0.002)\end{array}$ \\
\hline $\begin{array}{l}\text { CV }(3 \text { digit }) \times \text { Nonwhite } \times \\
\text { Promotion }\end{array}$ & $\begin{array}{l}0.115 \\
(0.088)\end{array}$ & $\begin{array}{l}0.113 \\
(0.088)\end{array}$ & $\begin{array}{l}0.116 \\
(0.088)\end{array}$ & $\begin{array}{l}0.114 \\
(0.088)\end{array}$ \\
\hline $\begin{array}{l}\text { (Coefficient of Variation) }^{2} \text { (3-digit } \\
\text { occupations) }\end{array}$ & & & $\begin{array}{l}-0.021^{* * *} \\
(0.005)\end{array}$ & $\begin{array}{l}-0.021^{* * * *} \\
(0.005)\end{array}$ \\
\hline Female & & $\begin{array}{l}-0.001^{* * * * *} \\
(0.000)\end{array}$ & & $\begin{array}{l}-0.001^{* * * *} \\
(0.000)\end{array}$ \\
\hline Age & & $\begin{array}{l}-0.000 \\
(0.000)\end{array}$ & & $\begin{array}{l}-0.000 \\
(0.000)\end{array}$ \\
\hline $\mathrm{Age}^{2}$ & & $\begin{array}{l}0.000 \\
(0.000)\end{array}$ & & $\begin{array}{l}0.000 \\
(0.000)\end{array}$ \\
\hline Tenure & & $\begin{array}{l}-0.000 \\
(0.000)\end{array}$ & & $\begin{array}{l}-0.000 \\
(0.000)\end{array}$ \\
\hline Tenure $^{2}$ & & $\begin{array}{l}0.000 \\
(0.000)\end{array}$ & & $\begin{array}{l}-0.000 \\
(0.000)\end{array}$ \\
\hline Level tenure & & $\begin{array}{l}-0.000^{* * * *} \\
(0.000)\end{array}$ & & $\begin{array}{l}-0.000^{* * * *} \\
(0.000)\end{array}$ \\
\hline$\left(_{\text {Level tenure })^{2}}\right.$ & & $\begin{array}{l}0.000^{* * * *} \\
(0.000)\end{array}$ & & $\begin{array}{l}0.000^{* * * * *} \\
(0.000)\end{array}$ \\
\hline Married & & $\begin{array}{l}0.000 \\
(0.000)\end{array}$ & & $\begin{array}{l}0.000 \\
(0.000)\end{array}$ \\
\hline Part time & & $\begin{array}{l}-0.000 \\
(0.001)\end{array}$ & & $\begin{array}{l}-0.000 \\
(0.001)\end{array}$ \\
\hline Constant & $0.006^{* * *}$ & $0.014^{* * * *}$ & $0.002^{*}$ & $0.010^{* * * *}$ \\
\hline
\end{tabular}




\begin{tabular}{|l|l|l|l|l|}
\hline & $(0.001)$ & $(0.002)$ & $(0.001)$ & $(0.002)$ \\
\hline No. obs. & 76,784 & 76,784 & 76,784 & 76,784 \\
\hline Robust standard errors in parentheses. Statistical significance at the 1\%, 5\%, and 10\% levels is denoted by \\
$* * *, * *$, and *, respectively, using one-tailed tests for Nonwhite, Coefficient of Variation (3 digit), and the \\
interaction of these two variables, and two-tailed tests for all other coefficients.
\end{tabular}

